Geological-Geophysical

Investigations of Bedrock in

the Island Falls Quadrangle,

Aroostook and Penobscot

Counties, Maine

$\begin{array}{lllll}\text { GEOLOGIGAL SURVEY PROFESSIONAL PAPER } & 527\end{array}$ 



\section{Geological-Geophysical}

Investigations of Bedrock in the Island Falls Quadrangle,

\section{Aroostook and Penobscot}

\section{Counties, Maine}

By E. B. EKREN and F. C. FRISCHKNECHT

GEOLOGICAL SURVEY PROFESSIONAL PAPER 527

Description of the stratigraphy and structure

of lower Paleozoic rocks in the Island Falls

quadrangle and the results of using geophysical techniques to trace certain strata beneath covered areas

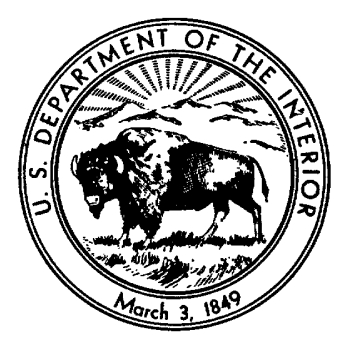




\section{UNITED STATES DEPARTMENT OF THE INTERIOR \\ STEWART L. UDALL, Secretary \\ GEOLOGIGAL SURVEY \\ William T. Pecora, Director}

Library of Congress catalog-card No. GS 67-152

For sale by the Superintendent of Documents, U.S. Government Printing Office Washington, D.C. 20402 


\section{CONTENTS}

Abstract

Introduction . . . .

Purpose and scope

Geography

Acknowledgments.-1-1.

Stratigraphy

Cambrian(?) System

Grand Pitch Formation.

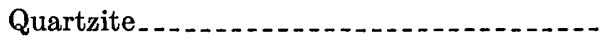

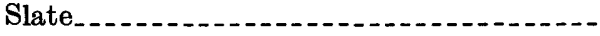

Stratigraphic relations and age..........

Ordovician System

Shin Brook Formation

Volcanic rocks and slate of the Mount Chase

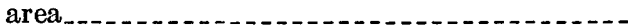

Spilite

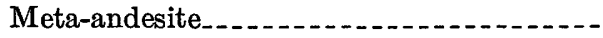

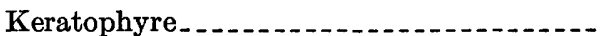

Quartz diabase and quartz-hornblende diabase

Felsites and pyroclastic rocks

Slate

Stratigraphic relations and age

Sedimentary rocks and greenstone on Kilgore

Knoll _. ........

Rockabema Quartz Diorite

Petrography ...............................

Chemical composition. . . . . . . . . . . .

Age

Ordovician or Silurian System...-.

Mattawamkeag Formation...................

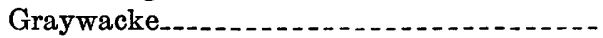

Slate and siltstone.......................

Stratigraphic relations and age

Silurian System

Conglomerate

Allsbury Formation. . . . . . . .

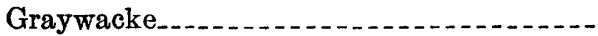

Slate_...

Quartzite.................................

Limestone. . . . . . . . .

Limy beds at Mill Brook .............

Stratigraphic relations and age.

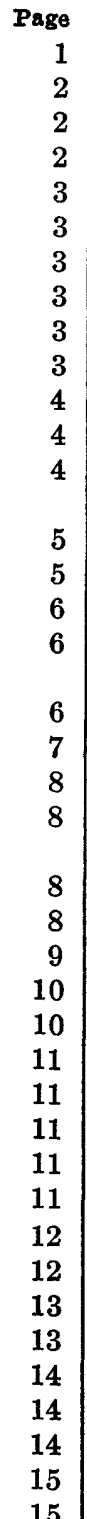

Stratigraphy-Continued

Silurian System-Continued

Rocks of Island Falls.......... 15

Limestone. .

Slate and sandstone........ 15

Stratigraphic relations and age.......... 16

Undifferentiated sedimentary rocks and quartz porphyry . .

Devonian System._.

Seboomook Formation

Granite of De Lette Ridge............... 18

Quartz monzonite and granodiorite of the Is-

land Falls area.... 18

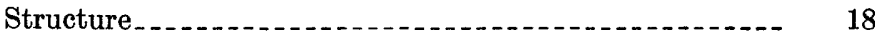

Folds

Major folds ......... 18

Transverse fold at Crystal Lake and Webster

Brook

Minor folds........... 19

Faults

Fault at Baston and East Hastings Brooks...-. 20

Fault at Lane Brook ................ 20

Possible fault along the Mount Chase front. ... 20

Possible fault at Kilgore Knoll _._._._._._._. $\quad 21$

Cleavage and its relations to structure

Metamorphism_............. 21

Effects on mineralogy ........ 21

Origin of albite in the volcanic rocks _._._._.

Summary of geologic events._............ 22

Economic geology

Geophysical investigations . . . . .

Slingram method. . .

Equipment and field techniques............ 24

Interpretation of electromagnetic profiles . - . - $\quad 25$

Grand Pitch Formation.-...... 27

Allsbury Formation and rocks at Kilgore

Knoll. - 28

Experimental traverses................. 28

Summary of electromagnetic results......... $\quad 30$

Magnetic surveys.......... 33

References cited .

\section{ILLUSTRATIONS}

Puate 1. Geologic map of the Island Falls quadrangle, Maine. In pocket

2. Aeromagnetic map and electromagnetic profiles. 
FIGURE 1. Index map showing location of Island Falls and adjacent quadrangles referred to in this report......... 2-6. Thin-section sketches:

2. Light-greenish-gray quartzite from the Grand Pitch Formation

3. Green-gray medium- to coarse-grained feldspathic graywacke from the Mattawamkeag Formation -

4. Very fine grained feldspathic graywacke from the Allsbury Formation

5. Slate-bearing graywacke from the Allsbury Formation

6. Medium- to coarse-grained arkosic quartzite from the Allsbury Formation....

7. Sketch of circuit layout, slingram apparatus

8. Model curves of slingram method.

9-13. Graphs showing comparison of profiles for electromagnetic traverses:

9. $\mathrm{T}-59 \mathrm{X}$

10. $\mathrm{T}-73 \mathrm{X}$

11. $\mathrm{T}-85 \mathrm{X}$

12. $\mathrm{T}-94 \mathrm{X}$

13. $T-95 X$

14. Graphs showing comparison of ground magnetic and electromagnetic profiles

\section{TABLES}

TABLE 1. Modes of quartzite and quartz graywacke

2. Modes and chemical analyses of four volcanic

3. Chemical analyses of Rockabema Quartz Diorite

4. Comparison of Rockabema Quartz Diorite with igneous boulder 


\title{
GEOLOGIGAL-GEOPHYSICAL INVESTIGATIONS OF BEDROGK IN THE ISLAND FALLS QUADRANGLE, AROOSTOOK AND PENOBSCOT COUNTIES, MAINE
}

\author{
By E. B. Ekren and F. C. Frischknecht
}

\begin{abstract}
The geology of the Island Falls quadrangle was studied by means of electromagnetic and magnetic surveys in conjunction with conventional geologic mapping techniques.

Bedrock in the quadrangle ranges in age from Cambrian(?) to Devonian and consists dominantly of graywacke and slate. The oldest strata are part of the Grand Pitch Formation of Cambrian(?) age. The Grand Pitch Formation crops out in the northern part of the quadrangle; it consists of black to medium-gray slate (some of which is conductive) and finely laminated gray siltstone and quartzite. Quartzite and quartzrich grit form only about a fourth of the volume but are a conspicuous part of the formation. The Grand Pitch is unconformably overlain by conglomerate, tuffaceous sandstone, and ash-fall tuff of the Shin Brook Formation of Early or early Middle Ordovician age. The Shin Brook Formation is generally confined to troughs of synclines in and around Green Mountain. Northwest of Green Mountain the formation is absent, and the Grand Pitch is overlain by Silurian strata. To the southeast, on the other hand, the Grand Pitch is overlain by or is in fault contact with thick spilite and keratophyre lava flows of Ordovician age that may be contemporaneous in part with the tuffaceous strata of the Shin Brook. The lavas form a rugged topographic ridge that extends across the quadrangle from Mount Chase northeast to Shoaler Mountain. The lava pile is about 12,000 feet thick at Mount Chase and about 3,000 feet thick at Shoaler Mountain. Numerous sills of medium-grained spilite or albite diabase occur within the extrusive strata along the Mount Chase ridge. These are presumably genetically related to the lavas.
\end{abstract}

The southeastern half of the quadrangle is underlain by a thick monotonous sequence of cyclically bedded conglomeratic graywacke, graywacke, varicolored slate, and thin-bedded limestone and siltstone. These strata have been divided into the herein-named Mattawamkeag Formation of Silurian or Ordovician age, the Allsbury Formation of Early Silurian age, and the rocks of Island Falls of Silurian age. Thick beds of conglomerate crop out just east of Patten along the Aroostook County line, at Crystal Lake, and at Bear Brook. The conglomerate contains cobbles and boulders of greenstone and quartz diorite that are believed to be locally derived. The conglomerate probably correlates with conglomeratic strata in the Stacyville quadrangle that contain fragments of Silurian brachiopods.

Two stocks of quartz diorite measuring 8 miles by 3 miles and 2 miles by about 1 mile, respectively, are present in the north-central part. The quartz diorite, named herein the Rockabema Quartz Diorite, intrudes strata of the Grand Pitch and Shin Brook Formations and the spilite lavas; it is in. tensely sheared and brecciated. Boulders of quartz diorite that are petrographically very similar to the rock in the stocks are found in the conglomerate beds that crop out east of Patten and at Bear Brook. The stocks are therefore considered to be younger than early Middle Ordovician and older than Silurian in age.

A small elongate stock of coarse-grained granite less than a mile long occurs along the east border of the quadrangle near De Lette Ridge, and the western margin of a large stock of granodiorite and quartz monzonite is present along the east border just east of the town of Island Falls. The intrusive rock in both stocks is fresh and unaltered, and postdates the major structural deformation of the Island Falls area. Potassium-argon age determinations of rock from the larger stock indicate a late Early or Middle Devonian age.

With the exception of the granitic rocks along the east border all the rocks in the quadrangle have been intensely deformed. Dips of less than $70^{\circ}$ in bedded strata are uncommon, and cleavage is well developed throughout. The mineral assemblage indicates that the Island Falls area is in the chlorite zone of regional metamorphism.

Electromagnetic surveys employing the slingram method delimited and traced many zones of conductive black slate in the Allsbury and Grand Pitch Formations. Commonly a series of conductors occur together in a zone which may be several hundred feet wide, although isolated conductors representing single beds $20-30$ feet wide are common. In the Allsbury Formation, narrow belts of conductors were traced as far as 10 miles. The delineation of these black slate zones was an invaluable aid in correlating strata from outcrop to outcrop, and also in determining the strike and extent of large folds.

Electromagnetic results from surveys of the Grand Pitch Formation were more complex than those from the Allsbury Formation, and individual anomalies seldom could be correlated between widely spaced traverses. Apparently there is considerable local folding in the black slates which does not parallel the regional strike, or else faults are present that could not be discerned in the field. Several belts containing many individual beds of conductive black slate were outlined; in many localities the buried contact between the Grand Pitch Formation and younger rocks was located by electromagnetic traverses.

The published aeromagnetic map of the quadrangle provided a valuable framework for the geologic studies. The volcanic rocks, the Allsbury Formation, and the baked rocks surrounding the granite stocks in the eastern part of the quadrangle are most magnetic. Ground magnetic surveys indicate that the anomalies in the Allsbury Formation result chiefly from black slate, which is often conductive as well as magnetic. 


\section{INTRODUCTION PURPOSE AND SCOPE}

Large areas of Maine are underlain by thick sequences of graywacke and slate. These rocks are not resistant to erosion and are very poorly exposed through the blanket of glacial drift. It is almost impossible to project contacts accurately in these areas, and geologists have long felt the need of a geophysical means of mapping contacts from one isolated outcrop to another. For this purpose, several methods may be used. In the iron range country of the United States, ground magnetic and, to a lesser extent, electromagnetic surveys are used to trace iron formations and other magnetic or conductive units. In parts of Canada adjacent to Maine, electromagnetic surveys made in a search for ore have provided very valuable geologic information of a more general nature by outlining large belts of conductive carbonaceous or graphitic slates. Reconnaissance electromagnetic surveying in several quadrangles in northern and eastern Maine during the summers of 1957 and 1958 (Frischknecht and Ekren, 1960) revealed that many black slates there are conductors. Traverses in the southeast corner of the Shin Pond quadrangle just west of the Island Falls quadrangle indicated the presence of several northeast-striking conductors in gently rolling terrain where the bedrock was almost completely covered by glacial drift. Reconnaissance geologic mapping by $\mathbf{R}$. B. Neuman (oral commun., 1958) suggested that the strata containing the conductors in the Shin Pond quadrangle occur also in the Island Falls quadrangle and there constitute the bulk of the bedrock in the southeastern half of the quadrangle. To determine the extent of this conductive bedrock and to evaluate ground electromagnetic surveys supplemented by magnetic surveys as a possible major aid to geologic mapping, a study of the geology of the Island Falls quadrangle was undertaken. The two geophysical methods as well as conventional geologic mapping techniques were employed in the study, which was begun in July 1959 and completed in October 1961.

In this report Ekren wrote the descriptions of stratigraphy and structure, and Frischknecht wrote the section on geophysical investigations. The authors are jointly responsible for the interpretation of structure and the correlation of units based on the results of the geophysical surveys.

\section{GEOGRAPHY}

The Island Falls quadrangle lies in northeastern Maine (fig. 1) astride the Penobscot-Aroostook County line, south of the main potato-producing country of northern Maine and east of Baxter State Park, the

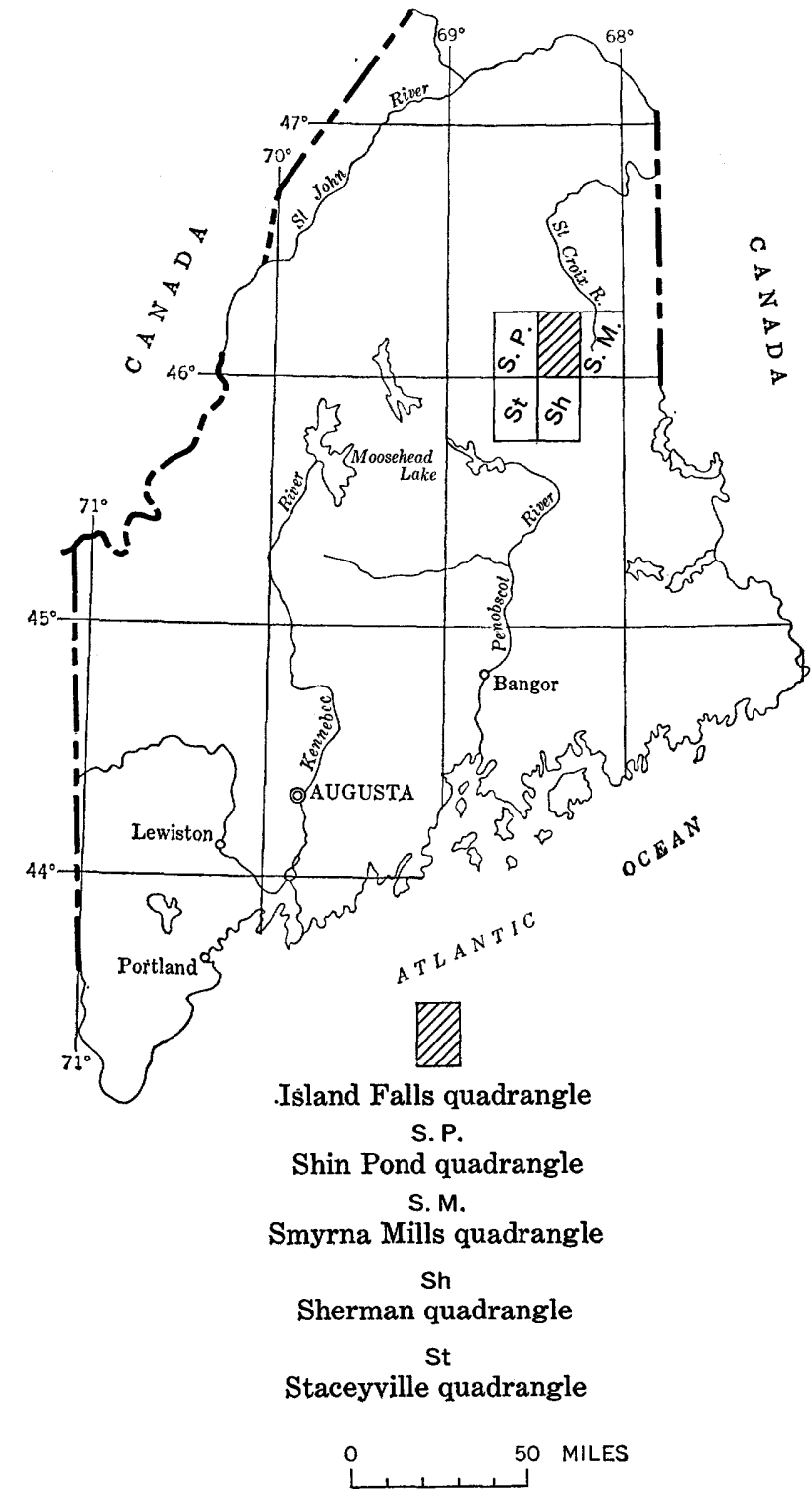

Figure 1.-Location of Island Falls and adjacent quadrangles !referred to in this report.

heart of Maine's wilderness area. The West Branch Mattawamkeag River is the principal stream; it is navigable by canoe from State Highway 11 in the north-central part of the quadrangle to the town of Island Falls in the extreme southeastern part. Patten and Island Falls are the only towns, both served by the Bangor and Aroostook Railroad. Lumbering, mainly for pulp, is the principal industry.

Elevations range from about 450 feet in the southeast corner to 2,440 feet at the summit of Mount Chase in the west-central part. A prominent ridge extends northeastward from Mount Chase across the quadrangle and divides the quadrangle into two distinctly 
different parts. To the northwest the land is rugged and covered with forest; to the southeast the land is gently rolling, and much of it has been cleared. Roads and trails are abundant in the southeastern part but scarce in the northwestern part.

Bedrock is exposed in approximately 5-10 percent of the area, mainly in streambeds and on the rugged ridge that extends from Mount Chase to Shoaler Mountain. The remainder of the area is covered with glacial drift that varies in thickness from a few feet to slightly more than 150 feet. The drift is thinnest in the southeastern part and thickest near Pleasant Lake, where preglaciation streams had cut a broad valley. Two wells just west of Pleasant Lake at Shin Pond in the Shin Pond quadrangle produce water from glacial drift at depths of about 160 feet.

\section{ACKNOWLEDGMENTS}

Robert B. Neuman of the U.S. Geological Survey had nearly completed the mapping of the adjacent Shin Pond quadrangle prior to the start of the Island Falls study. During his mapping, Neuman made several geologic traverses in the Island Falls quadrangle and had partly delineated the general structure and stratigraphy. The results of his reconnaissance work, made available to the authors, greatly facilitated the present study. Mr. Neuman also offered many constructive suggestions and ideas during the course of the study and the preparation of this manuscript. Louis Pavlides, mapping in the adjacent Smyrna Mills quadrangle, spent several days in the field with the authors, acquainting them with some of the stratigraphic units common to both quadrangles.

During the summer of 1959, A. S. Barwick was a geologic field assistant, and in 1960 he mapped independently in the field. Dallas Jackson served as geologic field assistant in 1961. Keith McElroy of Patten, Maine, was employed all three summers as surveying assistant and brush cutter. His intimate knowledge of the area, ability to handle a canoe, and cheerful spirit contributed greatly to fieldwork efficiency.

\section{STRATIGRAPHY CAMBRIAN (?) SYSTEM GRAND PITCH FORMATION}

The oldest rocks exposed in the quadrangle are part of the Grand Pitch Formation (Neuman, 1962, p. 794), formerly the Grand Falls Formation of Ruedemann and Smith (1935, p. 354). The type locality of the formation is the Grand Pitch of the East Branch Penobscot River a few miles west of the Island Falls quadrangle.
The Grand Pitch Formation underlies a broad area in the northern part of the quadrangle (pl. 1) but is poorly exposed. It consists of thin- and thick-bedded gray and dark-gray quartzite, coarse quartzitic grit, and conglomeratic quartzite interbedded with black to gray and, less commonly, green and green-gray thinbedded slate and siltstone. The formation was mapped as two units, on the basis of the occurrence of conductive strata. The conductive zones consist mostly of black slate but include minor amounts of thin-bedded quartzite and siltstone. The nonconductive zones contain relatively more quartzite and siltstone and less slate, which is dominantly gray or green gray.

\section{QUARTZITE}

About a fourth of the Grand Pitch Formation in the quadrangle is made up of quartzite, quartzitic grit, and sparse conglomeratic quartzite and quartz graywacke. The rocks, though very hard, are highly fractured and interbedded with slate; therefore, they are not resistant to erosion. Areas underlain by beds of quartzite are commonly marked by abundant angular quartzite boulders intermixed with glacial debris.

The quartzite occurs in even beds a few inches to several feet thick. Although the Grand Pitch as a whole is well stratified, stratification is generally obscure within single beds, and this is true for most of the quartzite. In places, however, quartzite that grades to siltstone and slate is finely cross laminated. The laminae are commonly varicolored in shades of gray, black, and white. A distinctive feature in outcrops of both fine-grained quartzite and coarse grit is the abundance of veinlets of white quartz, which rarely exceed an inch in thickness and average considerably less. The veinlets are anastomosing and in places form stockworks.

The quartzite (fig. 2) contains, on the average, more than 80 percent quartz. Accessory minerals include plagioclase, zircon, garnet, tourmaline, and leucoxene. Magnetite, pyrite, and carbon are locally abundant. The magnetite is dominantly secondary, occurring as tiny euhedral octahedrons. The rock contains chlorite that is pseudomorphically derived from biotite.

Modes of two quartzites and a quartz graywacke are shown in table 1.

SLATE

Slate in the Grand Pitch Formation is characterized by sharply curved cleavage planes caused by cross folding that deformed an earlier cleavage. The slate might best be termed curly slate; upon weathering it breaks into splinters and small curved fragments. Occurrence of such characteristic splinters can be used to distinguish the Grand Pitch Formation from younger rocks in areas of poor exposure or complex structure. 
BEDROCK GEOLOGY, ISLAND FALLS QUADRANGLE, MAINE

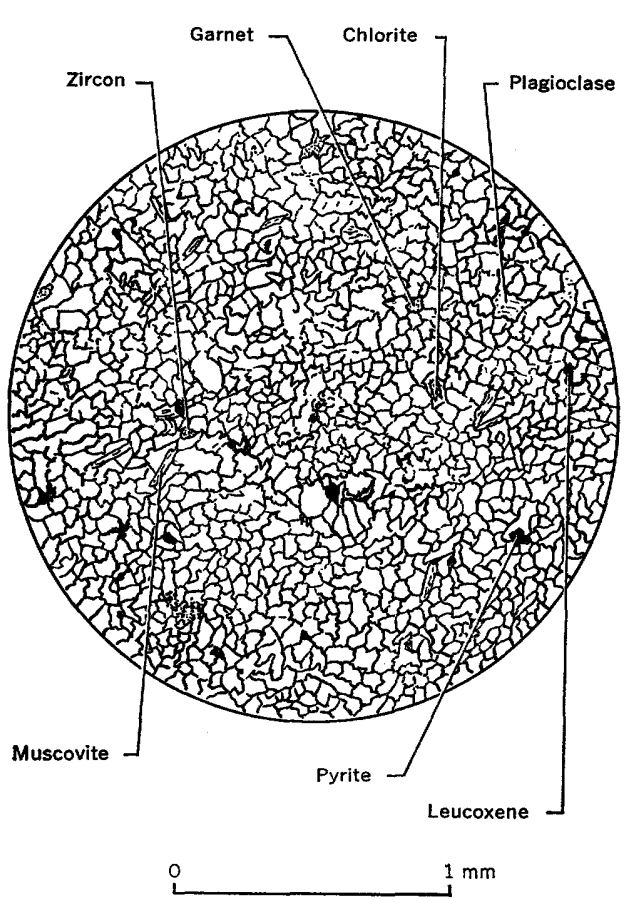

FIgURE 2.-Light-greenish-gray quartzite from the Grand Pitch Formation. The rock is a mosaic of very fine grained quartz containing sparse accessory minerals, sericite, and chlorite. Contacts between grains of quartz are outlined in part by tiny shreds of sericite. The opaque grains are crystals of leucoxene that are yellowish white in reflected light. A single cube of pyrite is in lower right. Sample 59-B7, from new tote road to Rockabema Lake.

$\mathrm{T}_{\mathrm{ABLE}}$ 1.-Modes of two quartzites and a quartz graywacke

\begin{tabular}{|c|c|c|c|}
\hline & $59 \mathrm{~B} 7$ & 59IF8-3-1 & 60IF8-15-2 \\
\hline Quartz_. & 83.6 & \multirow{8}{*}{$\begin{array}{r}1.2 \\
8.8 \\
4.8 \\
1.2 \\
1.0 \\
.4 \\
.6 \\
.6 \\
\text { Tr. } \\
\text { Tr. }\end{array}$} & \multirow{3}{*}{$\begin{array}{r}65.6 \\
126.4 \\
1.2 \\
3.6\end{array}$} \\
\hline Potassium feldspar.............. & $\mathrm{Tr}$. & & \\
\hline Plagioclase & 6.4 & & \\
\hline $\begin{array}{l}\text { Chortite (ancludes green botite) } \\
\text { Chert }\end{array}$ & Tr. & & 1.2 \\
\hline Magnetite & $\begin{array}{l}8.0 \\
.8\end{array}$ & & \\
\hline Pyrite_........ & .4 & & Tr. \\
\hline Zircon- & Tr. & &.$\overline{4}$ \\
\hline $\begin{array}{l}\text { Tourmaline } \\
\text { Limonite }\end{array}$ & Tr. & & $\mathrm{Tr}$. \\
\hline Garnet..... & Tr. & Tr. & ...- \\
\hline Total & 100.0 & 100.0 & 100.0 \\
\hline
\end{tabular}

1 Matrix is mostly sericite with small amounts of chlorite and quartz and sparse carbon.

59B7. Light-greenish-gray quartzite exposed on old tote road about 0.5 mile west o intersection with State Highway 11 about 1.2 miles south of Knowles Corner 59IF8-3-1. Black quartzite exposed below log bridge at West Hastings Brook and Lane Brook tote road. Pond.
Park-green-gray quartz graywacke, from east bank of Green Mountain

Thin sections of two dark conductive slates indicate that they are quartz-sericite slates containing abundant carbon in the form of fine dust, tiny blebs, and thin films. Common accessory minerals are pyrite, magnetite, leucoxene, and zircon. Tiny needles of rutile are abundant in a highly conductive slate from the northernmost conductive belt in T. 7 N., R. $5 \mathrm{~W}$. The $\mathrm{X}$-ray analysis (Theodore Botinelly, written commun., 1960 ) indicates that the carbon in the slate is not graphite. The conductivity of the slate is apparently determined by the abundance of carbon and the arrangement of the carbon particles in the rock. From the outcrop it is not possible to distinguish the conductive from the nonconductive slate. In general, conductive slate is black or nearly black, whereas nonconductive slate is gray or green gray. Some black slates, however, were found to be nonconductive. This absence of conductivity may be due to discontinuity of the carbon blebs and films in these slates and, therefore, the absence of continuous paths for the electrical current.

\section{STRATIGRAPHIC RELATIONS AND AGE}

The Grand Pitch is angularly overlain by fossiliferous strata of Silurian age in the vicinity of Lane Brook in the northwestern part of the quadrangle; by fossiliferous volcanic strata of the Shin Brook Formation of Early or early Middle Ordovician age in the vicinity of Green Mountain and Townline Brook; and by volcanic rocks of the Mount Chase area of probable early Middle Ordovician age in the vicinity of Rockabema Lake.

The trace fossil Oldhamia smithi Ruedemann has been found in several places in the Shin Pond quadrangle (Neuman, 1962, p. 795-796). No other fossils have been found in the formation. Smith (1928) concluded from the occurrence of Oldhamia that the beds are of Cambrian age. Neuman (1962, p. 795-796), however, pointed out:

Several problems attend the use of Oldhamia as an index of Cambrian age. Objects classed under this name vary greatly in pattern; although most of these seem likely to be of organic origin, the nature of the organism that made them remains obscure. Ruedemann's (1942, p. 9) interpretation that they are the intrastratal feeding tracks of worms comparable to Chondrites is tenable. Previous descriptions have failed to note that the trails are raised ridges on the upper surfaces of bedding planes (or grooves on lower surfaces), a fact consistent with the feeding track interpretation.

Neuman (1962, p. 796) concluded that the Grand Pitch Formation is of Cambrian (?) age.

The complex structure of the Grand Pitch and the lack of a basal exposure precluded an accurate determination of its total thickness, which is undoubtedly several thousand feet.

\section{ORDOVICIAN SYSTEMI SHIN BROOK FORMATION}

The Shin Brook Formation (Neuman, 1964, p. E4) was named from exposures at Shin Brook in the Shin 
Pond quadrangle. At the type locality the formation consists of crystal tuff, volcanic conglomerate, and fossiliferous calcareous sandstone; there, it is about 1,000 feet thick.

In the Island Falls quadrangle the formation is very similar and includes a lenticular basal conglomerate, ash-fall tuff, conglomeratic tuffaceous sandstone, and sheared felsite or light-colored slate.

The basal conglomerate crops out in several places northeast of Pleasant Lake, and in those places it overlies quartzite and black slate of the Grand Pitch Formation. The conglomerate is highly lenticular and ranges in thickness from 0 to slightly over 100 feet. In most places the rock consists of pebbles of felsite, quartzite, and slate $1 / 2-2$ inches in diameter in a chlorite-rich sandstone matrix. The pebbles of quartzite and slate are clearly derived from the underlying Grand Pitch. Locally, the conglomerate contains boulder-size fragments of diverse volcanic rocks and quartzite. The conglomerate shows well-defined cleavage, and the softer pebbles and boulders have been slightly elongated and stretched parallel to cleavage planes. Bedding is generally poorly defined; where visible, it is even and shows fair grading.

The conglomerate is overlain by pale tan or greengray sheared slaty felsite in which visible grains are absent or rare, or by coarse calcareous tuffaceous sandstone and ash-fall tuff. In thin section the felsite or slate consists of sericite and very fine grained quartz; the sandstone and ash-fall tuff consist of abundant crystals of feldspar and granules of felsite in a matrix of quartz, chlorite, sericite, and calcite. The calcareous sandstone and tuff are evenly bedded and locally show good grading. Where no conglomerate is present the base of the Shin Brook is marked by felsite, by lightcolored slate, or by tuffaceous sandstone.

The Shin Brook Formation in the vicinity of Green Mountain and Townline Brook is characterized by lenticular beds of conglomerate and thick beds of calcareous tuffaceous sandstone, some of which are fossiliferous. The formation was not recognized along the northwest flank of the Mount Chase ridge, where lavas are in depositional or fault contact with the Grand Pitch. The volcanic strata there contain neither conglomerate nor fossiliferous beds of tuffaceous sandstone; however, the possibility exists that some of the strata at Mount Chase are of Shin Brook age.

Fossils were found in two localities (3 and 4, pl. 1) in tuffaceous sandstone. The following forms were identified by R. B. Neuman (1964, p. E10) :

Sample locality 4 (locality $G$ of Neuman, 1964): Platytoechia boucoti Neuman, 1964

Cystoid remains

232-388-67-2
Sample locality 3 (locality $H$ of Neuman, 1964) : Orthambonites robustus Neuman, 1964 Platytoechia boucoti Neuman, 1964 Cystoid remains

These brachiopods are among those found by Neuman in the Shin Pond quadrangle at Sugarloaf Mountain and Crommett Brook. He and Harry B. Whittington (Neuman, 1964, p. E23-E24, E33-E34) concluded that the fossils of the Shin Brook Formation indicate an Early or early Middle Ordovician age.

The Shin Brook Formation in the Island Falls quadangle ranges in thickness from 0 to about 1,000 feet,

\section{VOLCANIC ROCKS AND SLATE OF THE} MOUNT CHASE AREA

Rocks under this heading include a variety of lavas, intrusive sills, slate, and pyroclastic rocks on Mount Chase. Fine-grained diabase and intrusive diabase sills in the Lane Brook Hills and Green Mountain, though not contiguous, are considered to be correlative with lithologically similar rocks on Mount Chase and are included in the description. The sills were probably intruded during the same period of volcanic activity that gave rise to the thick pile of lavas on Mount Chase.

\section{SPILITE}

Most of the rock exposed in the vicinity of Mount Chase is dark-green ophitic spilite. ${ }^{1}$ Two types are recognized. One type is very fine grained and vesicular or amygdaloidal and commonly shows pillows. The other type is fine to medium grained, massive weathering, and nonvesicular. It forms sills throughout the quadrangle. The latter type was described separately in an earlier report (Ekren, 1961, p. D45) as albite diabase.

Thin sections indicate the spilite contains about 45 percent plagioclase, 20-45 percent augite (partly altered to chlorite, actinolite, and epidote), 2-10 percent titaniferous magnetite, and varying amounts of calcite, sphene, and pyrite. The degree of alteration varies considerably. In some thin sections, augite is fresh and clear, altered only along crystal edges and fractures to actinolite and chlorite; plagioclase (albite ${ }^{2}$ or oligoclase) may be water clear, or it may be cloudy and contain a few crystals of epidote and fine-grained chlorite and sericite. In other thin sections both augite and plagioclase are extensively altered. Grain

1 The term "spillte" is used herein without a genetic connotation. It denotes a nonschistose basalt or diabase whose feldspar is albite or ollgoclase. The possibility that the sodic feldspar originated by $\mathrm{Na}_{2} \mathrm{O}$ metasomatism rather than dynamometamorphism is discussed on page 21 .

2 Plagioclase compositions in most rocks were determined by comparing indices of refraction with balsam, measuring extinction angles, and determining optic sign. A few rocks were ground up, and plagloclase indices were determined by means of index oils. 
size varies from less than $0.1 \mathrm{~mm}$ in vesicular rocks to more than $5.0 \mathrm{~mm}$ in a few thick massive-weathering sills. Most amygdules in the vesicular rocks contain only calcite, but a few contain intergrown quartz, epidote, chlorite, and calcite. In all thin sections the principal ore mineral appears to be titaniferous magnetite that shows octahedral parting and is extensively altered to leucoxene-coated sphene.

\section{META-ANDESITE}

Meta-andesite crops out in several places along the ridge extending from Mount Chase to Shoaler Mountain. In hand specimen the rock closely resembles very fine grained spilite; it is medium green to dark green gray, very fine grained, and slightly porphyritic, containing no more than about 5 percent phenocrysts. In thin section the rock has a felty or pilotaxitic groundmass containing abundant microlites of plagioclase. The phenocrysts are plagioclase (albite and rare remnants of oligoclase or andesine) and augite, and are as much as $2 \mathrm{~mm}$ in length. Quartz occurs as tiny grains in the groundmass and fills interstices between microlites of plagioclase. Other groundmass constituents are sphene, chlorite, actinolite, epidote, sericite, and a few crystals of augite and pyrite. The rock contains a small amount of sericitized potassium feldspar and as much as 15 percent more total feldspar than is average for spilite.

Meta-andesite is probably less abundant than spilite, but because the two rocks are so similar megascopically, much meta-andesite may have been overlooked during mapping. The meta-andesite may be a considerable part of the total volume of volcanic rocks in the Island Falls quadrangle.

\section{KERATOPHYRE}

Rocks called keratophyres differ principally from the meta-andesite in having more albite, more abundant phenocrysts, and fewer mafic minerals. In the Mount Chase area, the rocks are blue, blue gray, green, and green gray. Very few are amygdaloidal.

The only phenocryst in much of the keratophyre is cloudy albite, which shows mottled extinction and contains abundant secondary epidote or calcite. Some rocks contain relatively unaltered augite phenocrysts, and a few uncommon rocks contain small amounts of orthoclase. The phenocrysts average less than $3 \mathrm{~mm}$ in length, few exceed $5 \mathrm{~mm}$; they make up 5-30 percent of the rock. Most of the rocks examined in thin section have felty or trachytic groundmasses containing abundant microlites of albite and tiny crystals of epidote or clinozoisite, chlorite, actinolite, calcite, and sphene. Magnetite is locally abundant as discrete grains and tiny veinlets. In one rock, magnetite has replaced parts of groundmass crystals and also phenocrysts of albite (Ekren, 1961, p. D44). A few rocks have finely granular groundmasses that were probably originally glassy.

Orthoclase-bearing keratophyre is not distinguishable from other keratophyres in the field, and in thin section the orthoclase phenocrysts have a peculiar patchy extinction caused by irregular patches of albite. Quartz is widespread, and some rocks are quartz keratophyre. The quartz occurs as tiny grains in the groundmass, as anhedral masses as much as $5 \mathrm{~mm}$ in diameter, and as veinlets.

Very few of the keratophyres are amygdaloidal; however, a keratophyre that crops out in the vicinity of Bear Mountain on the old tote road to Pleasant Lake contains so many large amygdules that in hand specimen it resembles a conglomerate. The centers of the amygdules are filled with quartz, which is surrounded by epidote and chlorite. The rock has a glomeroporphyritic texture; albite phenocrysts in clusters as much as $5 \mathrm{~mm}$ in diameter and augite up to $1.5 \mathrm{~mm}$ in diameter are set in a dense trachytic groundmass. The groundmass consists of microlites and tiny tabular crystals of albite, chlorite, actinolite, and sphene. An epidote-rich keratophyre with albite phenocrysts crops out on a steep knoll north of Mattawamkeag Hill. Quartz occurs as sparse phenocrysts and as a principal constituent in the groundmass. The groundmass quartz is micrographically intergrown with plagioclase. Staining tests indicate there is no potassium feldspar in the rock.

The abundance of secondary calcite and epidote in the plagioclase phenocrysts in these rocks, together with the mottled extinction of the albite, is clear indication that the albite is not a primary constituent. The keratophyres were probably produced by the alteration of dacitic and rhyodacitic lavas. Modes and chemical analyses of four samples of spilite, metaandesite, and keratophyre are listed in table 2.

\section{QUARTZ DIABASE AND QUARTZ-HORNBLENDE DIABASE}

Quartz-bearing diabase and quartz-hornblende diabase crop out in three of the volcanic belts in the Island Falls quadrangle - at Green Mountain, at Knowles Corner, and southwest of Pickett Mountain Pond. The rocks in all three localities are adjacent to intrusive masses of Rockabema Quartz Diorite.

The rocks are dark green to medium green and medium grained; except for quartz and hornblende, in outcrop they appear identical with the intrusive spilite.

A thin section of quartz-bearing diabase from Green Mountain shows virtually no plagioclase. Pseudo- 
TABLE 2.-Modes and chemical analyses of four volcanic rocks from the Mount Chase area

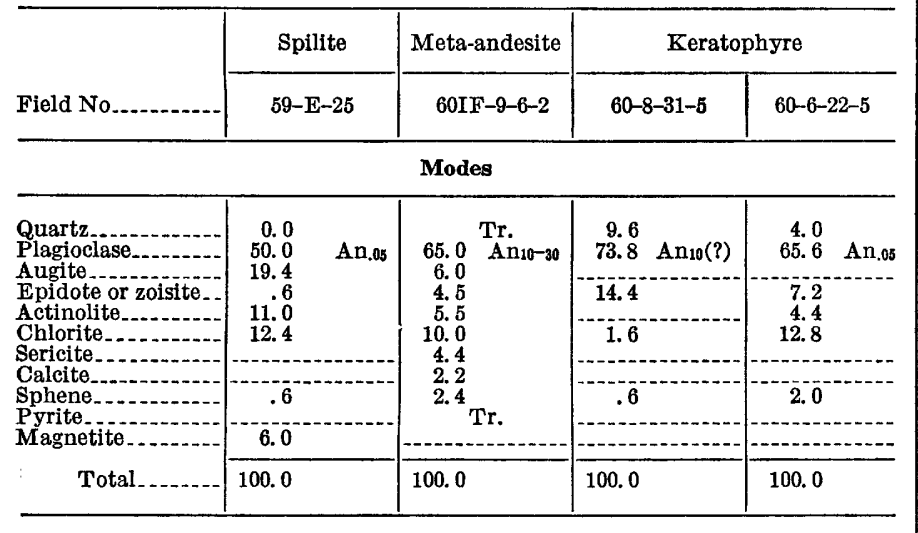

\begin{tabular}{|c|c|c|c|c|}
\hline \multicolumn{5}{|c|}{$\begin{array}{c}\text { Chemical analyses } \\
\text { [Ana]yst, P. M. Buschman] }\end{array}$} \\
\hline Lab. No........ & H3277 & H3280 & H3279 & H3278 \\
\hline 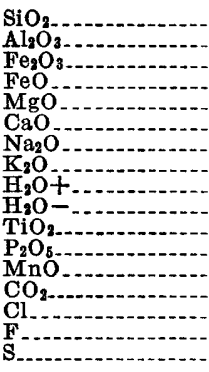 & $\begin{array}{r}51.67 \\
13.84 \\
3.39 \\
9.64 \\
5.19 \\
5.66 \\
5.50 \\
.15 \\
2.22 \\
.09 \\
1.89 \\
.15 \\
.28 \\
.02 \\
.00 \\
.03 \\
.03\end{array}$ & $\begin{array}{r}58.55 \\
15.24 \\
1.60 \\
4.72 \\
4.70 \\
4.51 \\
4.57 \\
2.16 \\
2.09 \\
.14 \\
.70 \\
.08 \\
.17 \\
.25 \\
.01 \\
.02 \\
.09\end{array}$ & $\begin{array}{r}74.11 \\
13.03 \\
1.26 \\
1.80 \\
.56 \\
2.59 \\
5.31 \\
.04 \\
.64 \\
.01 \\
.20 \\
.03 \\
.07 \\
.01 \\
.00 \\
.01 \\
.00\end{array}$ & $\begin{array}{r}63.14 \\
14.59 \\
1.89 \\
5.56 \\
2.16 \\
2.54 \\
6.12 \\
.05 \\
1.95 \\
.07 \\
.91 \\
.28 \\
.16 \\
.09 \\
.01 \\
.05 \\
.10\end{array}$ \\
\hline \multirow[t]{2}{*}{ Total } & $\begin{array}{r}99.75 \\
.02\end{array}$ & $\begin{array}{r}99.60 \\
.06\end{array}$ & $\begin{array}{r}99.67 \\
.00\end{array}$ & $\begin{array}{r}99.67 \\
.07\end{array}$ \\
\hline & 99.73 & 99.54 & 99.67 & 99.60 \\
\hline
\end{tabular}

59-E-25. From a sill that weathers to a massive outcrop on the north slope of Mattawamkeag

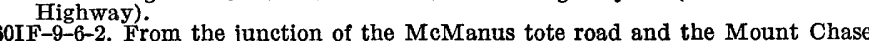

townline, about 2 miles northeast of Mount Chase.
$60-8-31-5$. From a newly blasted area on the new road to Rockabema Lake, about 250 feet west of the junction with State Highway 11, and 5,500 feet south of Knowles Corner.

60-6-22-5. From a location 4,000 feet southwest of the west shore of Pickett Mountain Pond, and 2,000 feet northeast of elevation 1370 on the north slope of the Mount Chase ridge.

morphs that appear to be after original laths and tabular crystals of plagioclase are filled with quartz, epidote, chlorite, and sparse albite. Original pyroxene has altered almost completely to chlorite, actinolite(?), and epidote. The rock contains as much as 20 percent quartz and 10 percent titaniferous magnetite. Another thin section from the same outcrop on Green Mountain contains 33 percent clear augite, 20 percent chlorite, and 37 percent plagioclase that is altered almost entirely to white, nearly opaque clay. Plagioclase remnants in this rock are calcic labradorite in composition. The rock contains about 7 percent quartz, possibly derived from the alteration or decomposition of plagioclase. Other constituents are epidote and leucoxenecoated sphene.

The rock in the vicinity of Knowles Corner contains abundant pale-green hornblende as well as quartz; it is a diorite. It is commonly a breccia that contains boulder-sized fragments of medium- to coarse-grained rock in a fine-grained matrix. In places the rock has been intruded by thin stringers of light-gray and green-gray Rockabema Quartz Diorite. Two thin sections of breccia from outcrops about half a mile apart are very similar. They contain as much as 26 percent quartz, which is partly interstitial and very fine grained and partly in the form of large crystals as much as $3 \mathrm{~mm}$ in diameter. The plagioclase is intensely altered, containing much clay, epidote, and sericite. Other principal minerals are unaltered palegreen hornblende and chlorite. The paragenetic sequence appears to be plagioclase followed by either hornblende or quartz. In one thin section, crystals of hornblende are poikilitic and enclose altered crystals of plagioclase and quartz. In the other thin section, however, quartz crystals commonly enclose crystals of hornblende. One rock contains several crystals of garnet, and both rocks examined in thin section contain abundant magnetite or ilmenite.

The rock exposed southwest of Pickett Mountain Pond contains 59 percent albite, 5 percent quartz, 28 percent hornblende, 5 percent epidote, 3 percent chlorite, magnetite, sericite, and apatite.

The quartz and hornblende in the diabase were probably formed by thermal metamorphism related to the intrusion of the Rockabema Quartz Diorite. The facts that support this conclusion are (1) the texture is intergranular or ophitic except that the ferromagnesian mineral is hornblende instead of augite, and (2) the only known occurrences of these rocks are adjacent to intrusive masses of quartz diorite.

\section{FELSITES AND PYROCLASTIC ROCKS}

Felsite and variegated pyroclastic rocks are scarce on Mount Chase but are more abundant both to the northeast and southwest. The southeasternmost exposure of volcanic strata in the vicinity of Bear Mountain and Seams Brook consists of sheared green rock that contains abundant fragments or ellipsoidal boulders and cobbles of greenstone in a matrix of finer grained greenstone and white-weathering chert. The fragments have a punky vesicular rind and are rich in magnetite. A similar rock on Wardsworth Mountain contains large rounded fragments of greenstone as much as 20 inches in length in an aphanitic red matrix. These rocks could be agglomerates, flow-breccias, or debris flows.

The southeasternmost exposure of volcanic strata along the Mud Lake tote road west of State Highway 11 is of sheared rock rich in phenocrysts of quartz. The rock exhibits vague bedding or flow layering. Two 
BEDROCK GEOLOGY, ISLAND FALLS QUADRANGLE, MAINE

thin sections show that the rock contains, in addition to quartz, a few grains of alkalic feldspar. These grains commonly have cores of quartz. The quartz phenocrysts are anhedral masses as much as $2 \mathrm{~mm}$ in diameter that consist of many individual grains with sutured contacts. The groundmass or matrix consists of fine-grained quartz, sericite, and minor calcite. Quartz appears as masses and large angular grains in two other thin sections from the same exposure but from more resistant strata. Those sections also contain a few euhedral grains of alkalic feldspar and a few small crystals of plagioclase. Calcite, pyrite, and magnetite are locally abundant. The exposed rocks are probably silicified rhyolite lavas or rhyolitic tuffs with intercalated ash-fall tuff. Similar rocks crop out in places farther along the Mud Lake tote road, at Seams Brook, on Mattawamkeag Hill, and on Shoaler Mountain.

SLATE

A thin zone of even-bedded dark-gray and purple slate and siltstone about 100 feet thick crops out northwest of Bear Mountain on the boundary between Moro and Hersey Townships, on the McManus tote road, at the Maine Forest Service cabin on the south slope of Mount Chase, and on Wardsworth Mountain. These outcrops form a nearly straight line; the slate is inferred, therefore, to be continuous between the outcrops in this area (pl. 1). On Bear Mountain, along the tote road that leads to Pleasant Lake, dark-gray slate is in contact with a massive-weathering mediumgrained sill of spilite. A thin section of the slate taken a few feet from the contact indicates the rock is rich in quartz and contains green biotite, garnet, and abundant magnetite. The garnet and magnetite are concentrated in elliptical blebs whose long axes are parallel to cleavage planes. Magnetite makes up about 10 percent of the volume of the rock and was probably formed with garnet during the intrusion of the spilite. Thin-bedded purple-gray siltstone and gray chert crop out on the north side of the sill. These rocks are also rich in magnetite but contain no garnet.

\section{STRATIGRAPHIC RELATIONS AND AGE}

The volcanic rocks of the Mount Chase area overlie the Shin Brook Formation of Early or early Middle Ordovician age northwest of Pleasant Lake and are older than the graptolite-bearing slate of Middle Ordovician age on Kilgore Knoll. The possibility seems good, therefore, that the volcanic strata of Mount Chase are of Early or early Middle Ordovician age. The lavas are probably genetically related to the tuffs of the Shin Brook Formation and some flows may have accumulated simultaneously with them. The bedded tuffs of the Shin Brook Formation are exposed near Green Mountain, the Lane Brook Hills, and in the adjacent Shin Pond quadrangle.

\section{SEDIMENTARY ROCKS AND GREFNSTONE} ON KILGORE KNOIX

Thin beds of fine-grained greenstone interbedded with black chert, black slate, and a few thin beds of green-gray quartzite crop out on Kilgore Knoll in what is probably a faulted anticline between the West Branch Mattawamkeag River and the old site of the Kilgore School. The black chert and slate give the strongest electromagnetic anomaly of any of the conductive strata in the Island Falls quadrangle.

The chert is coal black to blue black in the wet outcrop but when dry is medium gray. The chert is in beds a few inches to 5 feet thick and shows poorly defined cleavage. The interbeds of black slate, on the other hand, are well cleaved. Some of the black slate in a single outcrop contains numerous pyritized graptolites.

The following graptolites were found in black cherty slate at locality 5 (pl. 1). They were identified by W. B. N. Berry and are of Normanskill, Middle Ordovician age.

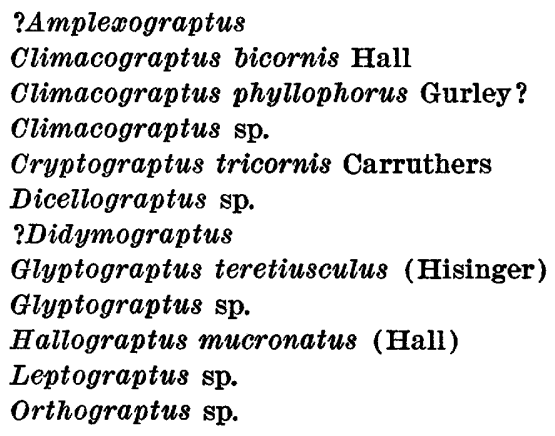

In outcrop, the fine-grained greenstone has a slightly different appearance from the spilite of Mount Chase. The difference is due to an overall lighter green color and a lack of amygdules, which are common in the fine-grained spilite in the vicinity of Mount Chase. Two thin sections were examined: one is rich in actinolite and clinozoisite, and calcite is scarce; the other is rich in calcite and chlorite and contains little or no actinolite, clinozoisite, or epidote. The feldspar is cloudy albite in both thin sections, and neither one contains quartz. The original texture was probably pilotaxitic, and the rocks may have been altered basalts or spilites.

\section{ROCKABEMA QUARTZ DIORITE}

The name Rockabema Quartz Diorite is here given to the intrusive rock that crops out in the vicinity of Rockabema Lake, Pleasant Lake, and Hastings Brook in T. 6, R. 6 W., and also in Moro and Merrill Town- 
ships, R. $6 \mathrm{~W}$. The best exposures occur along the northeast and north shore of Rockabema Lake, here designated as the type locality. Other good exposures occur along the southeast shore of Mud Lake, and, locally, along the south shore of Pleasant Lake.

Rockabema Quartz Diorite occupies the central part of the Weeksboro-Lunksoos Lake anticline in the vicinity of Rockabema and Pleasant Lakes, where it forms a large stock about 3 miles in width. It thins at the west boundary of the quadrangle but widens in the Shin Pond quadrangle near the Shin Ponds. A smaller stock of quartz diorite has been injected litpar-lit into the Grand Pitch Formation and volcanic rocks of the Mount Chase area in the vicinity of East and West Hastings Brooks. Here quartz diorite makes up about 50-60 percent of the total rock volume. Two small plugs of quartz diorite crop out on Green Mountain and Frost and Adams Ridge.

The intrusive igneous rock is not as resistant to erosion as surrounding strata, and outcrops are few. Exposures of the quartz diorite weather to form massive rounded outcrops, although cleavage is everywhere fairly well defined.

Along the southeast and east margins of the stock at Rockabema Lake, and in the smaller plutons at East Hastings Brook, Green Mountain, and Frost and Adams Ridge, the quartz diorite is so intensely sheared and brecciated that it is almost a schist. Exposures between West Hastings Brook and the northeast shore of Rockabema Lake indicate that sheared rock in the stock becomes gradually less abundant westward from West Hastings Brook. Along the northeast and north shores of Rockabema Lake the rock is not schistose and shear zones are rare. The significance of the schistose structure is not well understood. The shearing is possibly related to the inferred fault zone that forms the southeast boundary of the quartz diorite mass near Rockabema Lake; however, the fact that the smaller plutons are sheared throughout suggests that most of the schistose structure resulted from crushing and shearing during the intense Acadian folding, when the sedimentary and volcanic rocks were jammed tightly against the intrusive masses.

\section{PETROGRAPHY}

The large stock at Rockabema and Pleasant Lake is a composite mass containing two distinctly different types of rock. These are shown separately (pl. 1), but the contact between the two is very poorly defined and was never directly observed in the field.

Both types of rock are characterized by abundant crystals of quartz, but the rock at Rockabema Lake is very nearly equigranular whereas that at Pleasant Lake is distinctly porphyritic. At Rockabema Lake the rock is gray to green gray and medium grained and contains about 31 percent quartz, 10 percent potassium feldspar, 34 percent plagioclase, 5 percent hornblende, 12 percent chlorite, 6 percent epidote, and 1 percent calcite. The plagioclase is very cloudy and has been altered almost completely to albite, epidote, calcite, sericite, and a few flakes of chlorite. Most of the chlorite in the rock has been altered from hornblende, but some appears to have altered from biotite. Magnetite is sparse and is localized with chlorite and epidote in pseudomorphs after hornblende. Tiny veinlets of epidote and calcite are scattered through the rock. Quartz was formed after crystals of plagioclase and hornblende and fills interstices between them. Most of the crystals are 1-2 $\mathrm{mm}$ in diameter; a few quartz crystals are as long as $5 \mathrm{~mm}$, and a few hornblende crystals $10 \mathrm{~mm}$. The texture is hypidiomorphic granular.

The rock at Pleasant Lake contains large grains of quartz and plagioclase as much as $10 \mathrm{~mm}$ long in a groundmass of much smaller crystals of plagioclase, quartz, and chlorite. The quartz phenocrysts, commonly aggregates of several individual crystals, are more erosion-resistant than other crystals and therefore stand out on the surface of outcrops. Many of the large quartz crystals have nearly euhedral outlines and are surrounded by smaller grains of plagioclase. These quartz crystals were probably formed early during the crystallization of the magma. Other quartz crystals are late and fill interstices between grains of plagioclase and mafic pseudomorphs filled with chlorite, epidote, and locally sphene. Most of the mafic pseudomorphs appear to be after biotite rather than hornblende and contain abundant tiny radioactive zircon crystals that produce halos in the surrounding chlorite. The plagioclase in the rock at Pleasant Lake is intensely altered to calcite, epidote, sericite, and chlorite. The cores of the plagioclase crystals are much more altered than the outer hulls. Twinning is indistinct. The plagioclase remnants are albite or sodic oligoclase.

East and southeast of Mud Lake in the vicinity of Duck and Pickett Mountain Ponds, and northeast of Pleasant Lake near Spring Brook, the groundmass of the quartz diorite is much finer grained. This textural difference probably resulted from more rapid cooling of the intrusive mass toward the edges of the stock. The rock in these areas is green and weathers to white or light gray; near Pickett Mountain Pond it contains large xenoliths of ophitic greenstone derived from the spilite lavas of the Mount Chase area. Quartz forms the largest and most conspicuous phenocrysts in the fine-grained border or selvage of the rock. A thin sec- 
tion from Spring Brook contains about 55 percent phenocrysts, of which 35 percent is quartz, 61 percent plagioclase, and 4 percent mafic pseudomorphs. The plagioclase phenocrysts are albite in composition and contain abundant zoisite. The mafic pseudomorphs are filled with chlorite and sphene and are probably altered from titanium-rich biotite. The groundmass consists of albite, sericite, quartz, and chlorite. The green fine-grained border rock is considered to be contiguous with megascopically identical rock in the adjacent Shin Pond quadrangle.

The lit-par-lit injected rock at East Hastings Brook is mostly light gray and equigranular. In hand specimen it closely resembles the rock exposed at Rockabema Lake. In places, however, as in the bed of East Hastings Brook about 1,000 feet south of State Highway 212 between Knowles Corner and Smyrna Mills, the rock is porphyritic and green. Two thin sections show strong cataclastic textures. Mafic minerals have altered completely to chlorite; feldspars have altered in part to sericite, calcite, and chlorite; and quartz crystals have been strained and shattered. Pyrite is fairly abundant.

The intrusive rocks exposed on Frost and Adams Ridge and on Green Mountain were not examined in thin section. The rocks contain abundant phenocrysts of quartz, are green or gray green, and appear megascopically identical with the chlorite-rich porphyritic rock exposed near Pleasant Lake.

\section{Chemical compostition}

Three chemical analyses (table 3) of Rockabema Quartz Diorite indicate that the nearly equigranular rock at Rockabema Lake is $\mathbf{1 0 - 1 1}$ percent poorer in

TABLE 3.-Chemical analyses of Rockabema Quartz Diorite

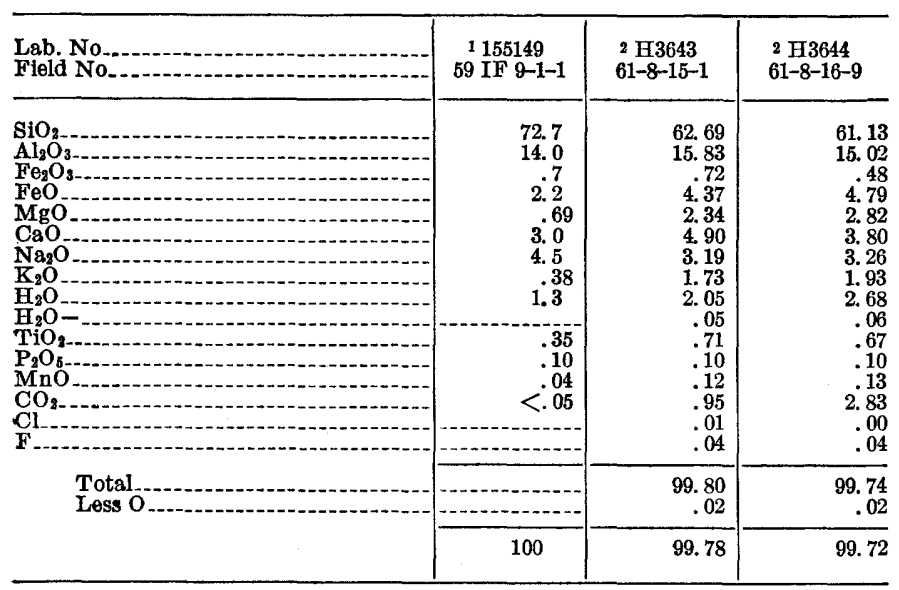

1 Rapld rock analysis by P. L. D. Elmore, S. D. Botts, I. H. Barlow, and Gillison Chloe.

i Standard rock analyses by P. M. Buschman.

59 IF 9-1-1. From the south shore of Pleasant Lake.

61-8-16-9. Intensely sheared; from West Hastings Brook. silica than the porphyritic rock at Pleasant Lake and is richer in total iron, magnesium, calcium, and alkali metals. The rock at Rockabema Lake contains 1.731.93 percent $\mathrm{K}_{2} \mathrm{O}$ whereas that at Pleasant Lake contains only 0.38 percent. The very low $K_{2} \mathrm{O}$ content at Pleasant Lake is unusual because the principal original mafic mineral was probably biotite. Apparently, some potassium ions migrated from the rock at Pleasant Lake during alteration; the relatively high $\mathrm{Na}_{2} \mathrm{O}$ content with respect to $\mathrm{K}_{2} \mathrm{O}$ suggests that some potassium ions in original feldspar lattices were replaced by sodium ions. Replacement is suggested also by the fact that at Shin Pond the selvage-quartz diorite, which is considered to be contiguous with the porphyritic border rocks in the Island Falls quadrangle, is relatively rich in $\mathrm{K}_{2} \mathrm{O}$ (table 4). The high $\mathrm{K}_{2} \mathrm{O}$ content of the rock at Shin Pond is not the result of assimilation of adjacent country rock, as the country rock there is metabasalt or spilite, characterized by very low $\mathrm{K}_{2} \mathrm{O}$.

Sample 61-8-16-9 is of highly sheared nearly schistose rock just east of Rockabema Lake. In chemical composition it is almost identical with nonsheared rock from the northeast shore of Rockabema Lake (sample 61-8-15-1); it is richer in calcite. (See high $\mathrm{CO}_{2}$ content in analysis.) The similarity of the two rocks indicates that the shearing and the development of a nearly schistose structure in the quartz diorite did not appreciably affect the overall chemical composition.

\section{AGE}

The Rockabema Quartz Diorite intrudes the Grand Pitch Formation of Cambrian(?) age, the Shin Brook Formation of Early Ordovician or early Middle Ordovician age, and the volcanic rocks of the Mount Chase area, which are about the same age as the Shin Brook. These relations are the only direct evidence of age; they indicate that the quartz diorite is later than Early Ordovician in age. Neuman (1960) first called attention to the occurence of the quartz diorite and gave two lines of evidence that the quartz diorite is probably of Ordovician age. An earlier age than Acadian is indicated by the intense alteration and deformation of the rock. All the granite intrusive masses of Acadian age in the Smyrna Mills quadrangle and other areas in northern and eastern Maine are relatively unaltered and uncleaved and are surrounded by hornfels rims. These hornfels rims commonly cause aeromagnetic anomalies; no significant anomalies occur along the border of the Rockabema Quartz Diorite except where magnetic volcanic rocks form one side of the contact. A pre-Silurian age is suggested by the occurrence of pebbles, cobbles, and boulders of quartz diorite in conglomerate lenses of Silurian age that crop out southeast of Mount 
Chase in the Island Falls quadrangle (pl. 1), and in several belts in the adjoining Shin Pond and Stacyville quadrangles.

Neuman's conclusion that the fragments of quartz diorite in the conglomerate were derived from the Rockabema Quartz Diorite is supported by petrographic and chemical data. Thin sections of several cobbles of quartz diorite from conglomerate exposed in the Island Falls and Shin Pond quadrangles indicate that the detrital material is nearly identical with the Rockabema intrusive rock. A chemical analysis of a boulder from a conglomerate lens exposed about $21 / 2$ miles west of the Island Falls quadrangle near the Allsbury Road (table 4) indicates that the composition of the boulder is very similar to the composition of the Rockabema Quartz Diorite in the stock at Shin Pond.

TABLE 4.-Comparison of Rockabema Quartz Diorite near Shin Pond with an igneous boulder from a conglomerate lens near Shin Pond

\begin{tabular}{|c|c|c|}
\hline \multicolumn{2}{|l|}{ Rockabema Quartz Diorite } & \multirow{2}{*}{$\frac{\text { Igneous boulder }}{\substack{\mathrm{H} 3645 \\
61-10-13-1}}$} \\
\hline $\begin{array}{l}\text { Lab. No } \\
\text { Field No-a }\end{array}$ & $\begin{array}{c}155148 \\
59 \mathrm{SP} 8-28-1\end{array}$ & \\
\hline 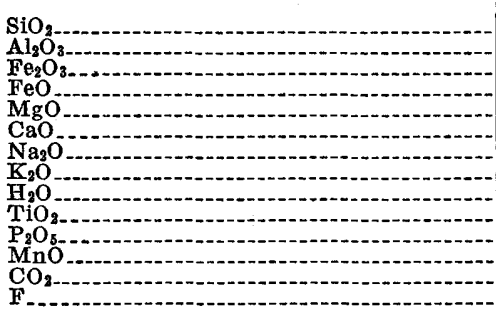 & \begin{tabular}{r|r|}
68.7 \\
15.1 \\
.9 \\
2.7 \\
1.2 \\
1.8 \\
3.6 \\
3.4 \\
1.7 \\
.46 \\
.12 \\
.10 \\
Not determined
\end{tabular} & $\begin{array}{r}66.47 \\
15.45 \\
.39 \\
3.12 \\
2.27 \\
1.76 \\
3.87 \\
2.66 \\
2.11 \\
.45 \\
.13 \\
.08 \\
.84 \\
.05\end{array}$ \\
\hline \multirow[t]{2}{*}{$\begin{array}{l}\text { Total } \\
\text { Less } 0 . .\end{array}$} & 100 & $\begin{array}{r}99.65 \\
.02\end{array}$ \\
\hline & - & 99.63 \\
\hline
\end{tabular}

59SP8-28-1. Rapid rock analysis by P. L. D. Elmore, S. D. Botts, I. H. Barlow, Gillison Chloe. Sample from outerop at upper end of Lower Shin Pond in roadcut of Shin Pond Road about 2 miles of Lst of Island Falls quadrangle.
w. 1-10-13-1. Standard rock aualysis by P. M. Buschman. Sample from boulder in conglomerate lens exposed about 1 mile west of Alsbury Falls quadrangle.

The Rockabema Quartz Diorite can, therefore, be dated conclusively between two limits; it is younger than the volcanic strata of Early or early Middle Ordovician age, which it intrudes, and is older than the conglomerate lenses of Silurian age. It is here classed as Ordovician.

\section{ORDOVICIAN OR SILURIAN SYSTEM}

\section{MATTA WAMKEAG FORMATION}

The Mattawamkeag Formation is named herein after the West Branch Mattawamkeag River. The best exposures and the type locality are at Warren Falls in the eastern part of the quadrangle near the east boundary of Hersey Township. The formation crops out in an area about 3 miles wide and about 10 miles long through Hersey, Dyer Brook, and Merrill Townships.

The rocks in the Mattawamkeag consist of about 50 percent slate and 50 percent siltstone and graywacke. The rocks are thin and thick bedded and are very similar to those in the Allsbury Formation, except that the slates are lighter colored and are not conductive.

\section{GRAYWACKE}

Graywacke in the Mattawamkeag Formation is almost entirely feldspathic, containing only small amounts of lithic fragments and averaging less than 50 percent quartz. The graywacke occurs in beds that range in thickness from about an inch to 25 feet but average about 1 foot. The beds are very well graded nearly everywhere; the finest examples of graded beds in the Island Falls quadrangle are in the Mattawamkeag Formation. The bases of the beds of graywacke commonly lie on scoured surfaces, and the beds in many places grade upward from coarse grit to fine slate within a vertical distance of 1 foot.

The graywacke contains abundant matrix consisting dominantly of fine-grained quartz, sericite, and chlorite. Because of the abundance of matrix and a general lack of siliceous cement, the beds are structurally incompetent, and slaty cleavage is almost as well developed in the graywacke as in the adjacent beds of mudstone and siltstone. In places the beds are intensely sheared and almost schistose. Angular to subangular grains of quartz and plagioclase form the framework of the graywacke (fig. 3).

\section{SLATE AND SILTSTONE}

Slate (mudstone) and siltstone are medium gray, green gray, and, in a few places, dark gray. Both show very well defined cleavage and, in places, grade to mica-rich phyllite. The beds of mudstone and siltstone are interbedded with graywacke and are 1 inch to 10 feet thick. In many places the rocks display fine cross laminations or convolute bedding.

In two thin sections of silty slate, both bedding and cleavage are visible; concentrations of quartz grains outline the bedding, and oriented shreds and tiny plates of sericite outline the cleavage. Chlorite is common.

\section{STRATIGRAPHIC RELATIONS AND AGE}

No fossils have been found in the Mattawamkeag, and the age of the formation is very uncertain. Top directions determined from graded beds along the northwest and southeast flanks of the area of outcrop 


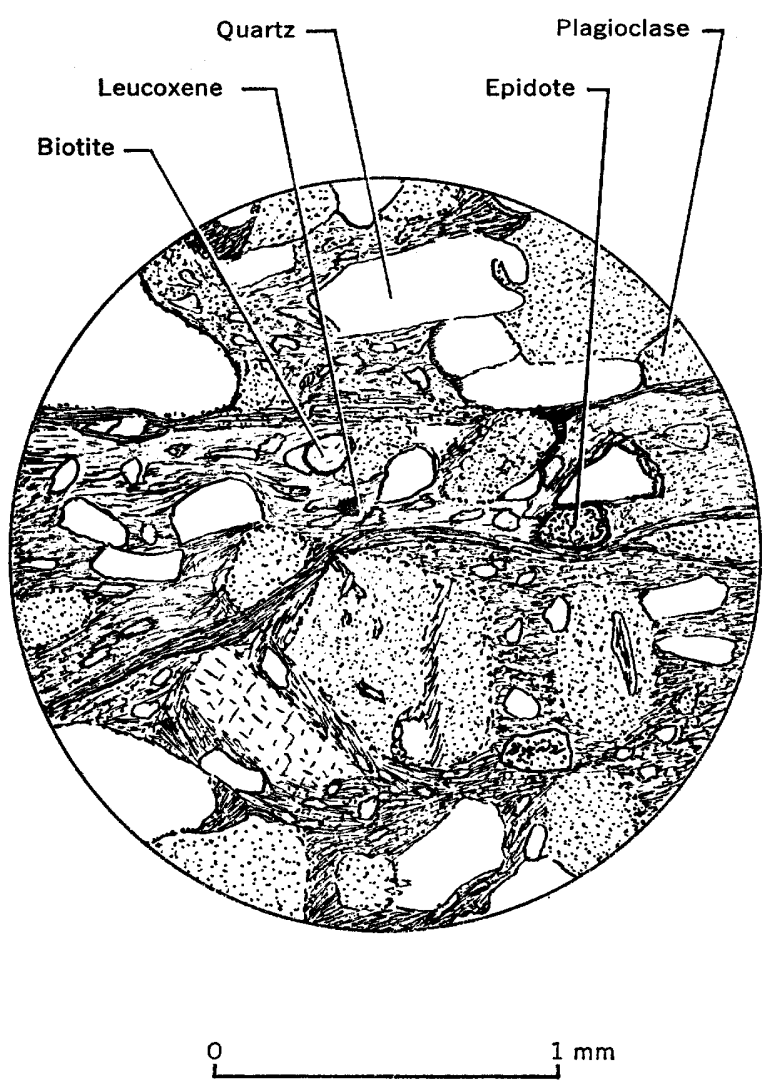

FIGURE 3.-Green-gray medium- to coarse-grained feldspathic graywacke from the Mattawamkeag Formation. The rock consists of large grains of quartz and plagioclase in a matrix of quartz, sericite, chlorite, and calcite. Biotite and epidote occur as sparse detrital grains. Plagioclase is intensely sericitized and many grains are not readily distinguished from the matrix. Sample 59 IF 7-30-7, about 0.3 mile east of the West Branch of the Mattawamkeag River on Halls Corner Road.

indicate that the Mattawamkeag is older than both the Allsbury Formation and the rocks of Island Falls and is probably, therefore, of Ordovician age. However, the possibility cannot be precluded that part or all of the Mattawamkeag is of Silurian age. It is here classed as Ordovician or Silurian.

\section{SILURIAN SYSTEM}

Silurian rocks crop out on both flanks of the Weeksboro-Lunksoos Lake anticline (Pavlides and others, 1964 , p. C28), but do not in themselves define this large fold. (See "Structure.") The strata in the two areas are distinctly different and reflect different depositional environments caused, at least in part, by the anticlinal barrier which was topographically high at the start of the Silurian Period. The rocks in the southeastern part will be described first.

\section{CONGLOMERATE}

A belt of strata consisting dominantly of gray to green-gray coarse-grained conglomerate, but containing interbeds of coarse grit, conglomeratic graywacke, and minor amounts of gray slate, crops out east of Patten along the Penobscot-Aroostook County line. The belt extends northward and northeastward through Crystal Lake, Seams Brook, and Houston Brook. Smaller patches of conglomerate crop out in the vicinity of Bear Brook and Alder Brook, and southwest of Lyman Brook.

The conglomerate is characterized by abundant pebbles and cobbles of light-gray and green-gray chert or felsite that commonly weather white. The rock contains, in addition to the chert or chertlike felsite, fragments of quartzite, quartz porphyry, and ophitic greenstone. A pebble count from a single outcrop along the Penobscot-Aroostook County line gave the following percentages: Chert or felsite, 42 percent; green volcanic rocks (mostly quartz rich, some quartz free), 28 percent; quartzite, 15 percent; quartz porphyry, 15 percent. Most of the quartz porphyry is identical with the Rockabema Quartz Diorite.

Pebble-sized fragments are most common in the conglomerate, but boulders and cobbles are locally abundant. In the vicinity of Crystal Lake, the conglomerate contains angular boulders of actinolite-rich igneous rock as large as 2 feet across and 4 feet long. A few boulders of limestone and jasper. occur locally, and in places slabs and boulders of slate are abundant. Most fragments, except the slate, are fairly well rounded. The matrix consists of quartz, chlorite, plagioclase, and sericite. The conglomerate occurs in even beds that range in thickness from several inches to several tens of feet.

Lenses of conglomerate that are identical with those in the Island Falls quadrangle crop out between the Allsbury Formation and the volcanic rocks of the Mount Chase area along the southeast limb of the Weeksboro-Lunksoos Lake anticline in the adjacent Shin Pond quadrangle. The possibility exists, therefore, that the conglomerate exposed east of Patten lies along the east limb of a broad synclinorium and is generally continuous at depth with the conglomerate at Shin Pond. The thickness of the conglomerate is believed to range from 0 to as much as 4,000 feet, which is the estimated maximum thickness of the belt east of Patten.

Recent finds of fragmentary brachiopods and other fossil debris by Neuman (1967) in the Stacyville quadrangle indicate an Early Silurian age for the conglomerate lenses. 


\section{ALLSBURY FORMATION}

The Allsbury Formation is named herein from exposures in the roadbed and roadcuts of the Allsbury Road, the type area, in the Island Falls and Shin Pond quadrangles. The formation crops out in a broad area in the vicinity of the road and consists dominantly of graywacke and dark-gray, black, and green slate. Thin beds of quartzite and coral-bearing limestone occur locally and were mapped separately. Many of the dark-gray and black slates in the formation are conductive and were traced by electromagnetic methods. The conductive zones consist mostly of black slate but include small amounts of graywacke. They contrast with the nonconductive zones in that sandstone (graywacke) is less abundant and the slate is richer in carbon.

\section{GRAYWACKE}

Graywacke occurs in graded beds and laminae that range in thickness from fractions of an inch to several

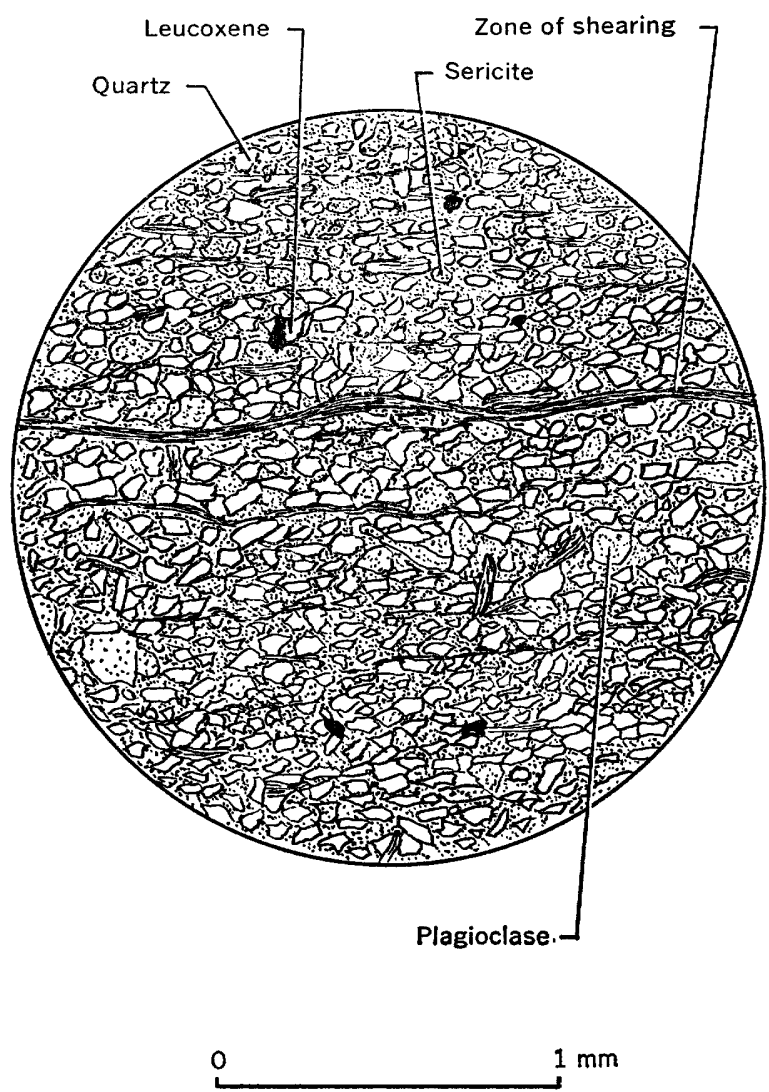

FIGURE 4.-Very fine grained feldspathic graywacke from the Allsbury Formation. The rock is noncalcareous and consists of about 40 percent angular quartz and 4 percent plagioclase in a matrix of quartz, sericite, and chlorite. A few crystals of biotite and a few chloritized mafic minerals are present. Sample 59-E-109, 2,800 feet east of Aroostook Scenic Highway along farm road leading east from Davis School.

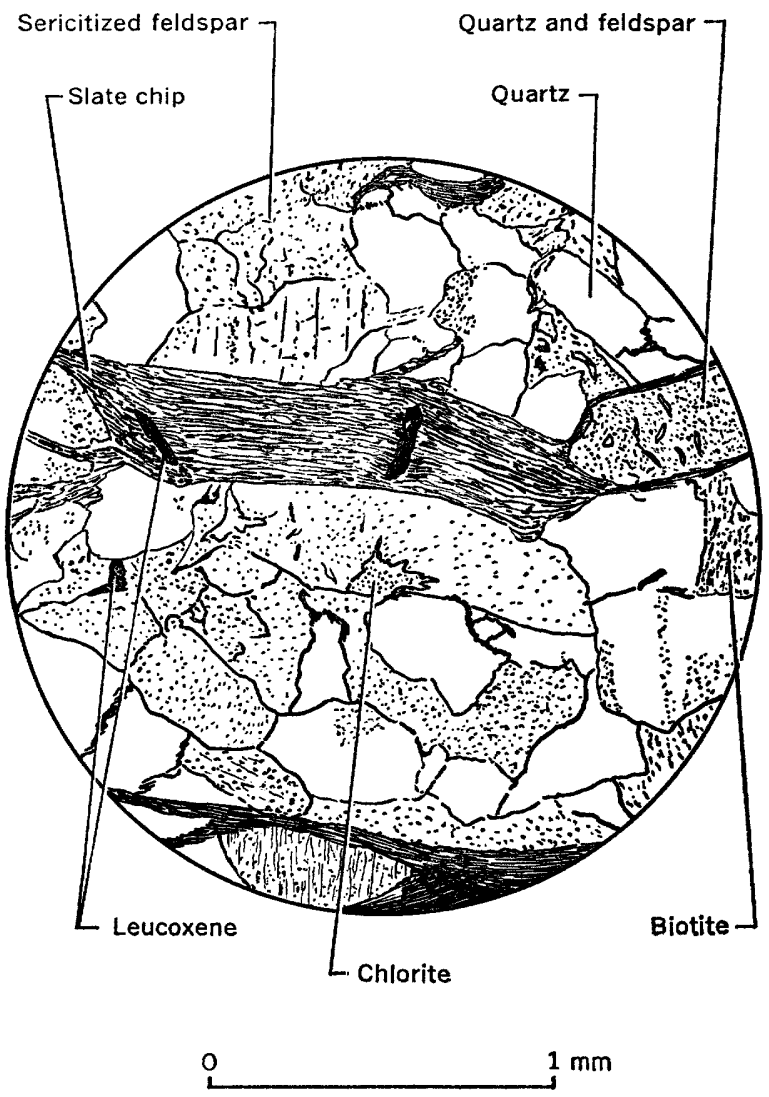

Figure 5.-Slate-bearing graywacke from the Allsbury Formation. The rock is a mosaic of quartz and feldspar and contains abundant chips of slate. The chips are very micaceous, containing both muscovite and biotite. Some chips are nearly black in transmitted light because of their abundant carbon. Except for the chips, the rock is moderately well sorted, and most grains range in diameter from 0.3 to $0.8 \mathrm{~mm}$. The grains are commonly not single crystals of quartz and feldspar, but are rock fragments containing both minerals. Many fragments display micrographic intergrowth of quartz and feldspar. Grains of perthite are common. Most of the feldspar has been extensively sericitized. Sparse films of dense mica between the grains indicate an original clay or mud cement. Sample 59 IF 7-30-4, north side of Batesville Road about 2,000 feet east of Bates Cemetery.

tens of feet. The graywacke (figs. 4 and 5) contains, on the average, more than 30 percent of detrital matrix composed of sericite, quartz, sericitized and calcitized plagioclase, chlorite, carbon, and a few grains of biotite. The framework fraction is quartz and albite; slate granules, cobbles and pebbles; and chloritized mafic minerals. Quartz makes up less than 50 percent of the volume, and plagioclase varies from about 5 percent to more than 40 percent. Most of the graywacke is pyritic. Cataclastic textures are marked in 
most thin sections; in outcrop the graywacke displays well-defined cleavage and in many places is nearly a sericite schist.

SLATE

Thin sections of three dark-gray and black slates from conductive belts reveal that the principal mineral is quartz; chlorite, sericite, and carbon occur in lesser amounts. Rutile (verified by $\mathrm{X}$-ray) is abundant as tiny needles. Tiny grains of tourmaline are common and pyrite is abundant, apparently occurring as two or more generations of crystals. The earlier pyrite crystals are surrounded by quartz. Magnetite is locally abundant and gives rise to small aeromagnetic anomalies.

The X-ray analysis of the blackest of the dark slates from a zone giving one of the strongest electromagnetic anomalies in the Allsbury Formation indicates that the carbon is not in the form of graphite (Theodore Botinelly, written commun., 1961). A thin section of the slate shows carbon in the form of spherical blebs or oolites $0.002-0.01 \mathrm{~mm}$ in diameter. Electron photomicrographs of carbon residue remaining after silicate minerals in the slate were dissolved in hydrofluoric acid, by a method described by Neuerburg (1961), show that the carbon oolites are hollow. Prior to treatment in acid the blebs or oolites had centers of silicate minerals-probably tiny grains of quartz. The conductivity of the slate results from the fact that the carbon oolites are interconnected and provide a continuous path for current to follow.

Thin sections of three green slates from the Allsbury show that they differ from the dark-gray and black slates only in their lower content of carbon. They consist mostly of quartz, sericite, and chlorite. Rutile and pyrite are common.

The green slates are confined mostly to the nonconductive zones in the Allsbury and are interbedded with gray and green graywacke.

\section{QUARTZITE}

Thin lenses of quartzite crop out between the Allsbury Road and State Highway 11 near Sargent and Houston Brooks in southeastern Mount Chase Township, at Jackson Sluice in Moro Township, and at Hale and Houston Brooks and near the Old Grub Road in Hersey Township.

The quartzite in southeastern Mount Chase Township, at Houston and Hale Brooks, and in the vicinity of the Old Grub Road consists of a single bed about 30 feet thick. The quartzite is pale tan gray and weathers tan gray or brownish gray. It is medium to coarse grained and locally contains quartz grains as large as $2 \mathrm{~mm}$ in diameter. A thin section from an exposure along the Old Grub Road (fig. 6) contains 73 percent quartz, 11 percent plagioclase, 6 percent potassium feldspar, 3 percent igneous rock fragments, and 6 percent chlorite and sericite. Accessory minerals include zircon, pyrite, garnet, magnetite, leucoxene, and apatite.

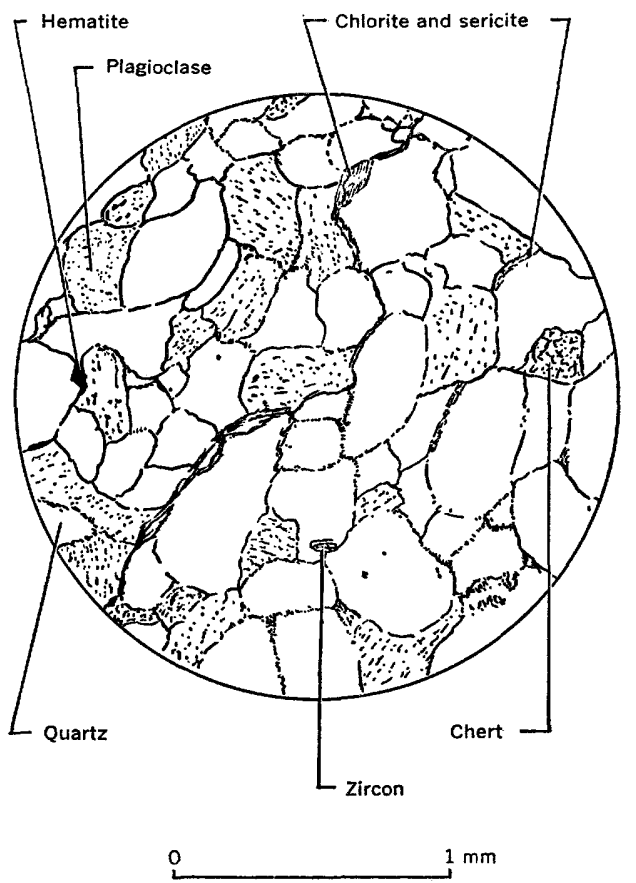

FIGURE 6.-Medium- to coarse-grained arkosic quartzite from the Allsbury Formation. The rock is a mosaic of quartz and plagioclase and contains very small amounts of potassium feldspar and chert. Sample 59 IF 7-27-7, about 1,500 feet south of Halls Corner Road on the Old Grub Road.

At the lower end of Jackson Sluice on the West Branch Mattawamkeag River, quartzite occurs in beds a few inches to 10 feet thick, interbedded with thinly laminated gray pyritic slate. The quartzite and slate zone is about 100 feet thick.

\section{IIMESTONE}

About 50 feet of thin- and thick-bedded medium- to purple-gray, buff-weathering limestone and calcareous slate or phyllite is exposed in the ditches and adjacent fields of Mill Road between Batesville and the site of the old Kilgore School. A single ledge of dark-gray limestone less than 20 feet in width is exposed in Bradford Brook, and several isolated ledges or massive boulders of medium to light-purple-gray limestone are exposed in a cedar swamp between Jackson Sluice and Kilgore Knoll in the vicinity of an old limestone kiln. The latter exposures are unusual for such a humid 
area in that the limestone weathers to massive boulders in the swamp, and the adjacent slate is almost completely covered. Early settlers quarried limestone from the massive boulders and burned or calcined the rock in the nearby kiln.

A thin section of limestone from the kiln area indicates that the rock is nearly pure calcite and contains less than 1 percent quartz as the only impurity. Grains of calcite averaging slightly less than $1 \mathrm{~mm}$ in size constitute the framework fraction (and major part) of the rock, and the interstices between the framework grains are filled with tiny grains of calcite and a few grains of quartz less than $0.1 \mathrm{~mm}$ in diameter. Locally, the rock contains abundant crinoid columnals as much as half an inch in diameter and fragments of tabulate corals. According to R. B. Neuman (oral commun., 1962), none of this material is diagnostic of age, although the large crinoid columnals suggest a postOrdovician age.

At Mill Road the limestone is interbedded with limy siltstone and gray calcareous slate and phyllite. The limestone contains abundant crinoid columnals, as in the kiln area, and is richer in fragments of tabulate corals.

\section{IIMY BEDS AT MILX BROOK}

Thin-bedded silty limestone and limy siltstone crop out at Mill Brook northeast of Batesville. The beds are not believed to correlate with the coral-bearing limestone beds just described. They average less than 4 inches thick, are gray to dark gray, and resemble very closely the thin-bedded limestone member of the rocks of Island Falls.

The beds appear to be isolated in the vicinity of the brook and are not shown separately on the geologic map (pl. 1). They were not found either to the northeast or southwest, although they may extend for considerable distances in both directions. The total thickness is probably less than 200 feet. Structural data are few in the area, and it is not known whether the calcareous strata are older or younger than the surrounding slate and graywacke.

\section{STRATIGRAPHIC RELATIONS AND AGE}

Neuman (written commun., 1962) found monograptids of Early Silurian age in conductive slate at several localities along the projected strike of the Allsbury Formation in the Sherman quadrangle just south of the Island Falls quadrangle. According to Neuman the rock is medium-gray to dark-gray pyritic slate and siltstone, interlaminated with sandstone layers $1 / 2-3 / 4$ inch thick. The lithology is typical of the Allsbury, and these occurrences, together with the fragmentary brachiopods found in the underlying con- glomerate lenses by Neuman (1967), establish the Allsbury Formation as Early Silurian in age.

The thickness of the Allsbury cannot be accurately determined because the rocks are tightly folded. It is probably a minimum of 1,000 feet in the northeast and at least 4,000 feet in the southwest.

\section{ROCKS OF ISLAND FALLS}

Thin-bedded silty limestone and calcareous siltstone and sandstone crop out in the extreme southeast corner of the Island Falls quadrangle. The rocks are well exposed at Island Falls and on May Mountain just northeast of the falls, but elsewhere in areas of low relief and abundant swamps they are very poorly exposed. Inasmuch as the limestone is abundant, the rocks are informally divided for mapping purposes into a limestone unit and a slate and sandstone unit.

\section{IIMESTONE}

Thin-bedded silty limestone and calcareous siltstone crop out in three narrow belts. The strata are even bedded and range in thickness from about a quarter of an inch to a foot. The calcareous siltstone averages less than 1 inch in thickness, and the silty limestone, which weathers to form recessed bands between ribs of siltstone on outcrop surfaces, averages less than 3 inches. The banded pattern is characteristic and is especially pronounced in the streambed exposures.

Rocks in the limestone unit are dark gray and weather blue gray and brown gray. Most of the beds are finely cross laminated, and drag folds are abundant. Veins of white calcite from a fraction of an inch to several inches thick are a conspicuous feature. The veins generally parallel the cleavage, but in places they crosscut both cleavage and bedding.

The limestone unit is placed in the same cartographic unit as the slate and sandstone because good exposures in several streambeds indicate that the contacts are gradational. The possibility exists that the unit correlates with the "ribbon rock" member of the Meduxnekeag Formation of Middle Ordovician to Early Silurian age, described by Pavlides (1962, p. 11-12), and Pavlides, Neuman, and Berry (1961, p. 65-67).

The limestone unit probably ranges in thickness from 0 to 3,000 feet.

\section{SLATE AND SANDSTONE}

At Island Falls and May Mountain, the rocks of Island Falls consist of medium-gray, green-gray, and dark-gray thin-bedded slate, siltstone, and very fine to fine-grained sandstone. Thin beds of silty limestone averaging less than 6 inches thick occur throughout. They are rare at the falls but are fairly abundant in exposures a short distance above and below the falls. The thickness of sandstone beds averages about 3 inches 
but is locally as much as 3 feet. The beds show fair grading and nearly everywhere are finely cross laminated.

The sandstone is quartzitic, and, in most exposures, calcareous. In one thin section, calcite makes up about 30 percent of the volume and quartz about 50 percent. The remainder of the rock consists of chlorite, sericite, and carbon. The volume of quartz determined in this thin section is believed to be about minimum for the sandstone in the Island Falls rocks. The abundance of quartz and calcite in the sandstone is a distinctive feature contrasting with the scarcity of these minerals in the adjacent feldspathic graywacke of the Mattawamkeag Formation.

The major constituents in the slate are quartz, sericite, calcite, chlorite, and carbon. A few grains of tourmaline are present, and the rock abounds in tiny needles of rutile.

The thickness of the slate and sandstone unit is probably less than 1,000 feet in the northwesternmost outcrops and reaches a maximum of 3,000 feet near Island Falls. (See section $A-A^{\prime}$, pl. 1.)

\section{STRATIGRAPHIC RELATIONS AND AGE}

Graptolites of Early, Middle, and early Late Silurian age have been found at several localities in a slate, siltstone, and quartzite sequence that crops out east of the Island Falls quadrangle in the Smyrna Mills quadrangle along the projected strike of the rocks of Island Falls (Pavlides and Berry, 1966). The nearest fossil locality is in Dyer Brook Township in a roadcut of U.S. Highway 2 about 3 miles northeast of the town of Island Falls. The rocks in the roadcut contain fossils of Middle Silurian age and are identical with the rocks at May Mountain in the Island Falls quadrangle. Thus, part of the sequence of Island Falls is of Middle Silurian age. The occurrence of the rocks of Island Falls stratigraphically above the Mattawamkeag Formation suggests that the lower part of the sequence is of Early Silurian age, inasmuch as it seemingly occupies the same stratigraphic position as the Allsbury Formation. If this inference is valid, the relative paucity of carbon and pyrite in the Island Falls rocks as compared with the Allsbury indicates that the Island Falls rocks were deposited in a more open marine environment. Louis Pavlides (written commun., 1965) suggested the possibility that the Mattawamkeag anticline (see "Structure") acted as a barrier between two basins during the deposition of the Allsbury and Island Falls rocks and thus enabled contrasting strata of similar age to form. This is a plausible explanation and may be a valid one; however, the data are inconclusive as to whether the Mattawamkeag anti- cline existed at all prior to the Acadian orogeny. The fact that the Island Falls rocks do contain carbon, although not as abundantly as the Allsbury, suggests that the depositional environments of the two units were similar. Perhaps the Allsbury Formation was deposited in a deeper basin of restricted circulation, a basin that lay nearer shore, as indicated by the relatively coarser clastics in these beds.

\section{UNDIFFERENTIATED SEDIMENTARY ROCKS AND QUARTZ PORPHYRY}

Undifferentiated rocks of Silurian age unconformably overlie the Grand Pitch Formation; they conformably underlie the Seboomook Formation in the vicinity of Lane Brook and the Lane Brook tote road in the northwestern part of the quadrangle. The rocks consist of conglomerate, limestone conglomerate, darkgray sandstone, and slate, and include a thin sill or lava flow of quartz porphyry at the top.

The base of Silurian rocks in the vicinity of Lane Brook is marked by a bed of coarse conglomerate containing pebbles, cobbles, and boulders of quartzite, large slabs of dark-gray slate, and a few concretions or boulders of brown-weathering calcite or recrystallized limestone. Most of the material has been derived from the Grand Pitch. In this area the conglomerate has been intensely brecciated and pyritized. Northeastward from the exposures in Lane Brook the bed of slate- and quartzite-bearing conglomerate pinches out or has been faulted out, and the oldest Silurian rocks are gray limestone and limestone conglomerate containing abundant fragments and boulders of coral. In West Hastings Brook at the north boundary of the quadrangle, the limestone conglomerate is in direct contact with the Grand Pitch and near the contact contains many angular fragments of quartzite that weather to sharp knobs on the surface of the limestone outcrop. The limestone conglomerate is overlain by calcareous sandstone and slaty siltstone, which in turn are overlain by the Seboomook. The sandstone and siltstone are gray and weather to brown, tan, and brownish red.

The strata exposed near the bench mark at elevation 916 feet appear to be very different from those at West Hastings Brook. The topmost rock of the Silurian section is green-gray quartz porphyry that consists of about 50-60 percent phenocrysts (mainly plagioclase and quartz) and 40 percent groundmass composed of sericite, chlorite, and very fine grained quartz. The rock contains abundant fine-grained magnetite or ilmenite that occurs with chlorite in pseudomorphs after biotite or hornblende. The magnetite probably accounts for the small aeromagnetic anomaly that coincides with the outcrop belt of Silurian strata. 
The first outcrop beneath the quartz porphyry consists of thin- and thick-bedded calcareous medium- to coarse-grained sandstone, sandy limestone, and darkgray calcareous siltstone. The siltstone contains abundant fossils (loc. 1, pl. 1). It is finely laminated at 2- to 3-inch intervals and weathers punky and tan or brownish red. Coral-bearing limestone conglomerate crops out about 1,000 feet southeast of the fossiliferous siltstone locality and an estimated 300 feet below the siltstone; however, fossil data indicate the limestone conglomerate is younger than the siltstone; therefore, the two outcrops must be separated by a concealed fault.

A. J. Boucot examined three collections of fossiliferous calcareous siltstone from a single outcrop near the bench mark at elevation 916 feet (loc. 1, pl. 1.) and concluded that the beds are of late Early Silurian age. The following forms were identified:

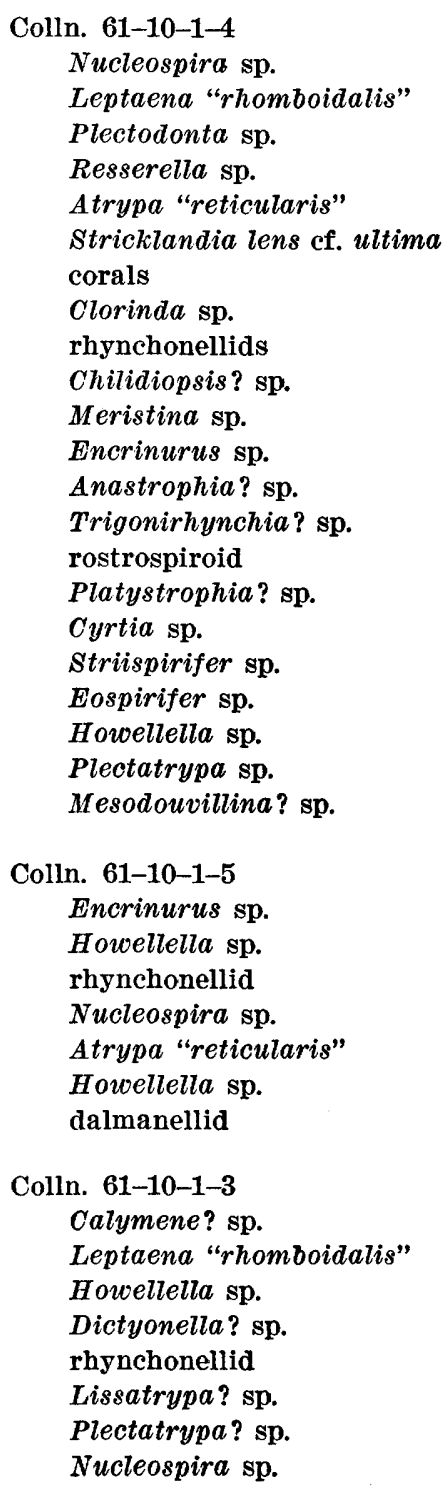

A Late Silurian age for the limestone conglomerate at sample locality 2 (pl. 1) is indicated by its corals, according to W. A. Oliver, Jr. (written commun., 1961).

\section{Colln. 60-E-1}

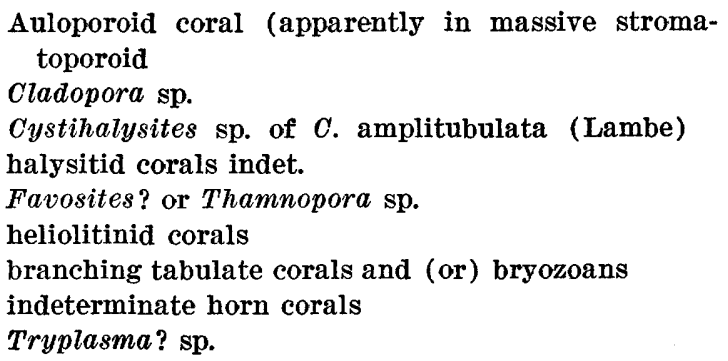

The Silurian rocks are about 600 feet thick near West Hastings Brook and about 1,500 feet thick near the bench mark at elevation 916 feet.

\section{DEVONIAN SYSTEM SEBOOMOOK FORMATION}

The Seboomook Formation (Boucot, 1961, p. 169171) was named from Seboomook Lake east of the report area. At the type locality it consists almost entirely of cyclically layered dark sandstone and slate. It may be as much as 20,000 feet thick.

The Seboomook crops out in the northwest corner of the quadrangle and consists dominantly of alternating cyclically layered dark sandstone and slate in graded beds. The sandstone beds average about an inch in thickness, show good grading to slate, and weather to ribs on the surface of the outcrop. The interbeds of slate or mudstone average about the same thickness as the sandstone. Bedding in the formation is generally conspicuous, but locally, near Weeks Brook and on the ridge northwest of Weeks Brook, the formation grades to thick beds of sandstone and mudstone in which bedding is difficult to discern. The rocks in the Seboomook are dark gray to dark green gray and commonly display a weathered rind that is light gray or tan gray and about $1 / 4-1 / 2$ inch thick. A thin section of sandstone indicates the rock is feldspathic graywacke containing about 50 percent of detrital matrix. The framework fraction is mainly subangular and angular quartz and includes a few grains of potassium feldspar and plagioclase. The matrix is mainly siltsize quartz, sericite, and chlorite. Heavy minerals include zircon, leucoxene, tourmaline, and apatite, which appear as tiny grains.

The Seboomook conformably overlies rocks of Silurian age in the Island Falls quadrangle, but the base of the formation has never been directly observed, and a disconformity or a minor angular unconformity may be present. The formation is about 5,500 feet thick 
in the Island Falls quadrangle, as measured along the south limb of the Wadleigh Bog syncline.

\section{GRANITE OF DE LETTE RIDGE}

A small stock or broad dike of medium-grained to pegmatitic granite crops out south and east of De Lette Ridge in the Smyrna Mills quadrangle. Abundant granite float suggests the mass is also present in the Island Falls quadrangle. The granite has baked adjacent sedimentary rocks of Island Falls, obliterating the cleavage and making the rocks more resistant to erosion. The baked rocks form a resistant ridge or rim on the west and north sides of the intrusive mass.

The granite is light gray, has a xenomorphicgranular texture, and contains 32 percent quartz, 37 percent perthitic feldspar, 27 percent albite $\left(\mathrm{An}{ }_{.55}\right)$, and about 4 percent muscovite. The plagioclase crystals have been slightly sericitized. Crystals of perthitic feldspar are the largest in the rock and range from about $3 \mathrm{~mm}$ to at least $20 \mathrm{~mm}$ in length. The granite weathers to large rounded blocks with no suggestion of cleavage, and the weathered surface is white and buff, and is commonly partly covered with a blueblack stain or varnish similar to desert varnish. In most places the granite is deeply weathered and feldspar crystals have altered to clay. At least 10 inches of surface rock must be removed before a fresh sample can be obtained.

\section{QUARTZ MONZONITE AND GRANODIORITE} OF THE ISLAND FALLS AREA

The presence of abundant float of quartz monzonite and granodiorite east of the town of Island Falls indicates that the large pluton in the adjacent Smyrna Mills quadrangle extends for a short distance into the Island Falls quadrangle. Pavlides and Canney (1964) named the mass the Pleasant Lake pluton after Pleasant Lake in the Smyrna Mills quadrangle. Potassiumargon age determinations of biotite (Faul and others, 1963) indicate a late Early or Middle Devonian age (385 million years) for the intrusive rocks.

\section{STRUCTURE}

The tectonic features and geologic history of northeastern Maine have recently been summarized by Pavlides, Mencher, Naylor, and Boucot (1964), who pointed out that the Paleozoic rocks throughout northeastern Maine are mostly incompetent pelites, limestones, and tuffs that have been thrown into steep-limbed folds. Local thick sequences of competent rocks such as those in the Chapman syncline 40 miles northeast of the Island Falls quadrangle are more gently folded and have moderate to gentle dips. In the Island Falls quadrangle the strata dip almost vertically; dips of less than $70^{\circ}$ are uncommon even in the relatively competent volcanic rocks of the Mount Chase area.

The rocks in the Island Falls quadrangle reflect both the Taconic and Acadian orogenies and also an earlier orogeny that folded the Grand Pitch Formation prior to the deposition of the Shin Brook Formation of Early or early Middle Ordovician age. The earlier orogeny has been named the Penobscot disturbance by Neuman (1967). Evidence for the angular discordance between the Grand Pitch and Shin Brook Formations is found in several outcrops in the vicinity of Green Mountain and Townline Brook, where strata in the Shin Brook dip about $70^{\circ}$ and strata in the Grand Pitch dip vertically. Ordovician strata were folded prior to deposition of conglomerate beds of Silurian age (Neuman, 1960; this report, p. 12). The conglomerate contains fragments believed to be derived from the Rockabema Quartz Diorite and from volcanic strata of the Mount Chase area. Such evidence suggests that the large Weeksboro-Lunksoos Lake anticline or an ancestral structural was formed during the Taconic orogeny. In the northwest part of the quadrangle Silurian beds angularly overlie the Cambrian(?) Grand Pitch Formation without intervening Ordovician strata. The lack of Ordovician strata, which are thick to the southeast, seemingly confirms the Taconic folding and subsequent deep erosion. In the southeast part of the quadrangle, however, Ordovician and Silurian rocks crop out side by side, show the same degree of deformation and metamorphism, and display no unequivocal evidence of being separated by an angular unconformity. The Taconic folding in the Island Falls area apparently gave rise to folds with broad intervening areas of relatively undisturbed strata, or a large fold that affected only the northwest part of the quadrangle.

During the Acadian orogeny the entire Island Falls area was intensely compressed, as shown by vertical dips in strata as young as Middle Silurian (the rocks of Island Falls) and steep dips in the Seboomook Formation of Devonian age.

Very weakly developed minor folds that are younger than cleavage in the southeast part of the quadrangle (see description of minor folds below) suggest that the Island Falls area was subjected to some tectonic activity younger than the main severe Acadian orogeny. This folding was not necessarily associated with igneous activity and probably reflects a late pulse of the Acadian folding.

\section{FOLDS MAJOR FOLDS}

The principal fold in the Island Falls quadrangle is the large anticline or anticlinorium at Pleasant Lake, 
named the Weeksboro-Lunksoos Lake anticline (Pavlides and others, 1964, p. C28). It plunges gently southwestward across the northwestern part of the area and exposes the Grand Pitch Formation. Its northwest limb is delimited by several synclines, principally the one that passes through Green Mountain and the Lane Brooks Hills (section $A-A^{\prime}$, pl. 1), within which Ordovician volcanic rocks dip at relatively gentle angles. The southeast limb of the anticline, however, is vertical or nearly so, and although faulted, it probably descends to considerable depth beneath the sedimentary strata of Ordovician and Silurian age to the southeast. These data suggest that the anticline is asymmetric. Pavlides and his collaborators (1964, p. C34) considered the Weeksboro-Lunksoos Lake anticline to be a northeast-trending fold whose southwest end near Lunksoos Lake in the Shin Pond quadrangle has been rotated to a southeast-trending fold by the drag of the Katahdin batholith. This conclusion may be valid; however, the anticline may have originally been north or northwest striking and the east limb may have been thrown into a series of northeast-trending folds by the severe Acadian folding. If this is so, the anticline at Pleasant Lake may not be the main fold. The fold at Pleasant Lake and the synclines at Green Mountain and Townline Brook may lie on the flank of a larger anticline whose axis is buried beneath the Silurian unconformity. This possibility is suggested by the apparent asymmetry of the anticlinal fold at Pleasant Lake, and by the Silurian strata resting directly on the Grand Pitch northwest of the synclines at Green Mountain and Townline Brook. If the anticline at Pleasant Lake is truly the crest of the main fold, it seems odd that only the northwest limb, which probably included thick sequences of competent volcanic rocks, has been stripped clean of Ordovician strata.

The rocks of the Grand Pitch exposed in the anticline are tightly folded and have been more intensely deformed and twisted by cross folding than any of the younger strata in the quadrangle. The overall strike of beds in the Grand Pitch is northeast, but in many areas this direction is masked by local crinkles and minor folds, and no attempt was made to map individual folds within the formation. The projection of the anticline through the area of Grand Pitch northeast of Pleasant Lake is based on the occurrence of conductive strata lying to the northwest and southeast and inferred to be on the limbs of the fold. (See p. 27)

Southeast of the Weeksboro-Lunksoos Lake anticline, the folds in rocks of Ordovician and Silurian age appear to be as tight as those in the Grand Pitch of Cambrian(?) age, but minor folds and cross folds are not as abundant. From northwest to southeast the sequence appears to be as follows: A synclinorium in which the Allsbury Formation is preserved, an anticlinorium in which the Mattawamkeag Formation is exposed, and a synclinorium in which the rocks of Island Falls are preserved. The anticlinorium is roughly outlined by conglomerate lenses of Silurian age, and the strata in this region nearly everywhere dip vertically. In the southeastern part of the quadrangle the beds are commonly overturned as much as $15^{\circ}-25^{\circ}$ from vertical.

The simplest fold in the Island Falls quadrangle is the Wadleigh Bog syncline, where strata of Silurian and Devonian age (pre-Acadian) have relatively gentle dips of $55^{\circ}-70^{\circ}$, and minor folds are absent or few. The strata in the Wadleigh Bog syncline are dominantly pelitic, and the relative openness of the fold, compared with folds in the southeastern part of the quadrangle, suggests an overall northwestward decrease in the intensity of deformation in the Island Falls quadrangle during the Acadian orogeny.

\section{TRANSVERSE FOLD AT CRYSTAL LAKE AND WEBSTER BROOK}

A northwest-plunging anticline is inferred from strike directions in the vicinity of Crystal Lake and Webster Brook. This inference is supported by aeromagnetic data which show a northwest trend in the vicinity of Webster Brook and a sharp change in strike about $1 \frac{1}{2}$ miles west of Crystal Lake. The data indicate that the rocks probably again change strike to the north or northwest on the east side of Crystal Lake and then gradually swing northeast. At Webster Brook the magnetic anomaly coincides with outcrops of graywacke and gray slate of the Mattawamkeag Formation. Conglomerate lenses to the west are relatively nonmagnetic. At Crystal Lake, however, the aeromagnetic anomaly appears to coincide partly with conglomerate.

The transverse folding is unusual in a region in which northeast-trending folds predominate. The Crystal Lake area was probably uplifted as well as compressed during folding; therefore, an intrusive plug or stock may underlie the Crystal Lake area.

\section{MINOR FOLDS}

Folds whose wavelengths and amplitudes range from a few inches to 20 feet are abundant in the Grand Pitch Formation, and they occur also in the rocks southeast of Mount Chase ridge.

Most of the folds in the southeast probably formed simultaneously with the major folds, but few are of the drag-fold type. Most have nearly equally inclined limbs and are locally of the chevron type. These folds 
do not appear to bear the same relation to the major folds that drag folds do. They are concentrated near the axial planes of the major folds, and nearly all the folds have very steep plunges. Most major folds, on the other hand, plunge at relatively gentle angles as deduced primarily from tracing of black slate zones by the electromagnetic method. Some belts of black slate were traced as far as 10 miles. Zones of this length are unlikely if all major folds plunge very steeply.

In a few places in the southeastern part of the quadrangle, especially near the town of Island Falls, there are younger minor folds that affect both bedding and cleavage. At Island Falls some of these are asymmetric, have south-striking axes, and appear to be related to the intrusion of the large stock that crops out in the adjacent Smyrna Mills quadrangle. Other minor folds strike east-northeast and are present at intervals throughout the southeast part of the quadrangle, far removed from any known intrusive mass. These folds are very weakly developed, but their axes appear to be nearly parallel to east-trending cross cleavage that is fairly well defined locally.

The minor folds in the Grand Pitch were formed both before and after the cleavage. Like the minor folds southeast of Mount Chase, these folds plunge very steeply. Their detailed relations to major folds have not been determined.

\section{FAULTS}

FAULT AT BASTON AND EAST HASTINGS BROOKS

A northwest-striking fault is indicated near Baston Brook east of Mattawamkeag Hill. The fault plane was not directly observed, but a line of springs east of Baston Brook presumably marks the fault trace. The fault is probably the principal cause of the sharp offset of the belt of volcanic strata of the Mount Chase area; however, electromagnetic data suggest that the offset is due partly to folding. At East Hastings Brook the fault either swings north or intersects a north- and northeast-trending fault that cuts through Shoaler Mountain. The course of East Hastings Brook changes from south to southwest at the fault line, where brecciated rocks of the Grand Pitch Formation are in fault contact with the Allsbury Formation. This juxtaposition indicates that the vertical displacement may be as much as several thousand feet.

North of Mattawamkeag Hill the fault is presumed to change strike to west and finally southwest, but its presence here is problematical. The inference that a fault is present in this area is based entirely on the occurrence of sheared and brecciated rock. Intensely sheared rock crops out along the north slope of Mat- tawamkeag Hill, and northwest-striking joints adjacent to the sheared rock support the inference that the fault trends northwest between Knowles Corner and Mattawamkeag Hill. Near Rockabema Lake, the fault zone trends northeast (locally north) and probably comprises three separate faults. One fault is on or adjacent to a small island at the southeast end of the lake. The island is elongated, trending north, and shear zones on the island also trend north. The rock consists entirely of breccia. In places the breccia consists of fragments of quartzite and slate derived from the Grand Pitch Formation; in other places the breccia consists almost entirely of fragments of Rockabema Quartz Diorite. The whole mass resembles a coarse conglomerate. Zones of slate are intensely pyritized locally, and the slate weathers to form yellow and black gossaniferous outcrops. A second northeast-trending fault is believed to pass about 1,000 feet southeast of the "island" fault and separates Rockabema Quartz Diorite from slate of the Grand Pitch Formation. This second fault is inferred solely from the occurrence of intensely sheared rock. A possible third fault passes about 1,000 feet southeast of this fault and separates sheared slate of the Grand Pitch Formation from sheared volcanic rocks of the Mount Chase area. Its presence is inferred from rocks in Atwell Brook, where several feet of mylonite or intensely sheared finegrained tuff is exposed. Rocks in this area are iron stained and locally pyritized. Southwest of Rockabema Lake the three faults are presumed to merge into a single fault, but outcrops are rare in this area and several faults could be present. Southwest of Pleasant Lake a single fault separates the Grand Pitch Formation from volcanic rocks of the Mount Chase area, and several feet of mylonite is exposed where the fault crosses a tributary of West Creek in T. 6, R. $6 \mathrm{~W}$.

FAULT AT LANE BROOK

Fossil localities 1 and 2 (pl. 1) are presumed to be separated by a fault; locality 2 , although in a stratigraphically lower position than locality 1 , yields fossils of younger age. (See p. 17.) There is no other evidence of a fault in the near vicinity. The location and the strike of the fault, therefore, are problematical.

\section{POSSIBLE FAULT ALONG THE MOUNT CHASE FRONT}

Several lines of evidence suggest that the contact between the Allsbury Formation and the volcanic rocks of the Mount Chase area may be a fault contact. Near the contact the strata are intensely sheared and brecciated. Locally, they are intensely pyritized, and, between Kilgore School and the Mattawamkeag River valley, they show a few faint stains of secondary copper minerals. Southwest of Mount Chase in the Shin Pond quad- 
rangle, the Allsbury Formation is separated from the volcanic rocks of the Mount Chase area by a thick zone of conglomerate, which is not present along the contact of the Allsbury with the volcanic rock in the Island Falls quadrangle. The conglomerate may be highly discontinuous and may not have been deposited here; however, its absence along the Mount Chase front may be due to elimination by faulting.

\section{POSSIBLE FAULT AT KILGORE KNOLL}

The belt of conductive slate and chert and associated greenstone of Ordovician age at Kilgore Knoll is surrounded by the Allsbury Formation of Early Silurian age. On the northwest side the belt appears to parallel a conductive zone in the Allsbury Formation, and the Ordovician-Silurian contact is probably normal. On the southeast side however, the greenstone is flanked by nonconductive sheared slate of the Allsbury; this contact may be a fault, as inferred on plate 1 . The inferred fault could account for the abrupt disappearance of Ordovician strata to the northeast and southwest.

\section{CLEAVAGE AND ITS RELATION TO STRUCTURE}

Cleavage is conspicuous in most of the strata in the Island Falls quadrangle. The average strike is northnortheast, and the dip is vertical or nearly so except in the area southeast of a line extending roughly from the intersection of Crystal Brook and Crystal Road through a point about midway between Stair Falls and Warren Falls. In this area the cleavage dips $55^{\circ}-85^{\circ}$ NW. Where good exposures are available it is apparent that the cleavage is not parallel to the axial planes of the major folds. Near Warren Falls, for example, top directions in graded beds of graywacke define a large syncline that plunges steeply to the northeast. In this area, cleavage strikes consistently N. $10^{\circ}-30^{\circ} \mathrm{E}$., which is more northerly than the strike of the bedding on either limb of the syncline. The cleavage, therefore, is younger than the major folds. According to M. P. Billings (oral commun., 1961), the cleavage probably formed under the same forces that produced the major folds, but after a slight shift in the applied direction. Relations between folds and cleavage in the nearby Maple and Hovey Mountains area of Aroostook County were described by Pavlides (1962, p. 30-31).

\section{METAMORPHISM EFFECTS ON MINERALOGY}

The Island Falls quadrangle lies in a regionally metamorphosed area that corresponds to the chlorite zone (Harker, 1956). The rocks have been intensely deformed by mechanical forces operating at low temperatures.
The chief minerals of the sedimentary rocks are sericite, quartz, and chlorite. The sericite and chlorite are apparently both authigenic, but there has been no recrystallization of detrital quartz. In many slates, for example, cleavage planes are outlined by tiny grains of sericite and chlorite, and bedding planes by grains of detrital quartz. The black slates contain abundant carbon, none of which has attained the crystal structure of graphite.

The pelitic sediments along the east border of the quadrangle near the De Lette and Pleasant Lake plutons (p. 18) have been baked to form hornfels rims that partly surround the intrusive igneous masses. Recrystallization during thermal metamorphism has obliterated slaty cleavage but has not affected bedding, which in places has actually been accentuated by color changes during metamorphism. On May Mountain, adjacent to the Pleasant Lake pluton, slate and sandstone contain quartz, biotite, tremolite, and actinolite. In some beds biotite is the principal constituent; in other beds in the same outcrop, biotite is sparse and actinolite is the principal constituent. These differences are not related to the distance of the bed from the intrusive mass but are due to original differences in the chemistry of individual beds.

Some of the hornfels on May Mountain contains as much as 20 percent pyrrhotite, which gives rise to an aeromagnetic anomaly (pl. 1). The hornfels on De Lette Ridge was not examined in thin section, but the grade of thermal metamorphism is probably about the same as that on May Mountain. The metamorphosed rocks, however, are confined to a much narrower belt.

No hornfels was observed around the stocks of quartz diorite near Rockabema Lake or East Hastings Brook. Thin sections of both quartzite and slate of the Grand Pitch Formation taken only a few feet from contacts with quartz diorite show the principal constituents to be quartz, sericite or muscovite, and chlorite. The lack of visible contact-metamorphic minerals in the Grand Pitch is probably due to two factors: (1) the rocks are rich in quartz, so that garnet, biotite, and other metamorphic minerals would not have tended to form in great abundance when the stocks were intruded, and (2) during subsequent regional metamorphism some metamorphic mineralsfor example, biotite and garnet-probably reverted to chlorite.

\section{ORIGIN OF ALBITE IN THE VOLCANIC ROCKS}

Plagioclase breaks down to form albite and epidote or zoisite in rocks subjected to low-grade regional metamorphism, as is well known. The problem in the Island Falls quadrangle is to determine whether the 
albite in the volcanic rocks resulted from dynamometamorphism or alkali metasomatism, or both.

Remnants of plagioclase as calcic as labradorite in some of the diabase in the Island Falls quadrangle eliminate the possibility that the sodic plagioclase was an original constituent. The albite was unquestionably formed after the rocks were emplaced. Two lines of evidence suggest strongly that some $\mathrm{Na}_{2} \mathrm{O}$ was introduced: (1) plagioclase crystals in the rocks are characterized by mottled extinctions, which are universally typical of replaced crystals, and (2) most of the basaltic rocks are nonschistose and retain their original ophitic or basaltic texture. Gilluly (1935, p. 342) pointed out, regarding the origin of albite in the diabasic-textured greenstones of the Baker quadrangle, Oregon:

The fact that, under low temperature conditions of rock formation, it is the rule for plagioclase to break down into albite plus some other minerals, is in itself suggestive that regional metamorphism may sometimes bring about the albitization of considerable rock bodies. On the whole, however, it is the habit of saussuritization to produce epidote or zoisite in the altered feldspar concomitantly with the albite. The retention of the ophitic texture of many albite diabases is evidence that any chemical changes they have undergone have been essentially metasomatic, so that albite has been introduced in equivalent volume to the anorthite expelled.

The almost universal association of spilitic rocks with a eugeosynclinal or marine environment has been considered by some investigators to be a vital clue to origin. Daly (1914, p. 338-340) was one of the first to suggest that spilites are a product of their sodium-rich submarine environment: he considered the albitization due to eruption through wet sediments. The volcanic strata in the Island Falls quadrangle are probably in large part, if not entirely, of submarine origin. They are overlain and underlain by marine strata, and they may well have been saturated throughout with marine water representing a tremendous reservoir of sodium ions. Recently Orville (1963, p. 201-237) and other investigators (in Orville, 1963) showed experimentally that alkali ions transfer readily in the vapor-alkalic feldspar system. Orville (1963, p. 236) concluded: "It is quite certain that connate waters, whatever their original alkali ratio may be, will approach equilibrium with alkali-bearing crystalline phases at comparatively low temperature ***." Dickinson (1962) described metasomatic quartz keratophyre formed from rhyodacitic ash-fall tuff associated with marine sediments in central Oregon. According to Dickinson (1962, p. 251), none of the Jurassic rocks associated with the quartz keratophyre have mineral assemblages indicative of the greenschist facies. The original tuff structure is well preserved, and the rock was apparently first zeolitized and then albitized. Dickinson (1962, p. 265) concluded that the tuff was converted to quartz keratophyre probably prior to the Late Jurassic or Early Cretaceous folding. He pointed out that the nearest and perhaps the only source of reactive fluids rich in sodium apparently was connate pore waters and adsorbed aqueous films that must have been expressed from associated and underlying marine mudstones by compaction.

The evidence as to the origin of the albite in the volcanic rocks of the Island Falls quadrangle is not conclusive, but in view of all the data, the most probable explanation is that the albite originated, in part at least, from alkali metasomatism.

\section{SUMMARY OF GEOLOGIC EVENTS}

1. The Grand Pitch Formation of Cambrian(?) age was deposited in an eugeosyncline in which a reducing environment prevailed.

2. The strata of the Grand Pitch Formation were folded and exposed to erosion.

3. The volcanic rocks of the Shin Brook Formation and the Mount Chase area were deposited on the eroded surface of the Grand Pitch Formation, probably during early Middle Ordovician time. (Possibly simultaneously with the volcanic eruptions, the Mattawamkeag Formation, consisting of feldspar-rich graywacke and slate, was deposited southeast of the centers of volcanic activity. Because of a lack of fossil dating of the Mattawamkeag, and uncertain stratigraphic relations, the formation is excluded from this sequence.)

4. A large anticline or anticlinorium was formed in the northwest part of the quadrangle at or near the close of the Ordovician Period, and a large stock of quartz diorite was intruded near Rockabema and Pleasant Lakes.

5. During earliest Silurian time, erosion and denudation of the anticline gave rise to deposits of conglomerate in the extreme northwest and southeast parts of the quadrangle.

6. Shale and graywacke of the Allsbury Formation, and silty limestone, shale, and sandstone of the rocks of Island Falls were then deposited in the southeast part of the quadrangle; siltstone and slate associated with coral-reef detritus were deposited in the northwest part. The coral-reef detritus apparently was derived from reefs that formed on topographically high parts of the old anticline.

7. The Seboomook Formation of Devonian age was deposited. 
8. The eugeosyncline, which had persisted intermittently from earliest Paleozoic time, was intensely buckled during the Acadian orogeny. This orogeny closed the eugeosynclinal cycle and was followed by the intrusion of granitic stocks of post-Early Devonian and pre-Late Devonian age.

9. The post-intrusion pre-Pleistocene record is lost in the Island Falls area. The region may have stood as a landmass since the Devonian.

\section{ECONOMIC GEOLOGY}

Mineral deposits of commercial value are unknown in the Island Falls quadrangle with the exception of extensive deposits of sand and gravel. Limestone in the vicinity of Bradford Brook was used by early settlers for fertilizer and lime plaster. It is still potentially valuable for such uses. The limestone consists locally of pure calcite, but the deposit is thin and limited in area. Small amounts of asbestos and talc occur in a few shear zones in the volcanic rocks of the Mount Chase area. The shear zones are only a few inches thick, and none of the material is considered to be of commercial value.

Finely disseminated pyrrhotite is found in hornfels at May Mountain. The pyrrhotite is in the form of tiny grains that range in diameter from about $0.01 \mathrm{~mm}$ to slightly over $0.1 \mathrm{~mm}$. In some outcrops the pyrrhotite makes up as much as 20 percent of the volume of the hornfels, and presumably causes an aeromagnetic anomaly that partly surrounds the stock at Island Falls. In places there may be sufficient pyrrhotite or other minerals in the hornfels rim to warrant detailed prospecting.

The most promising area for metallic mineral deposits is the south flank of the Rockabema intrusive mass at Rockabema Lake, where there are several fault zones containing pyrite and abundant iron oxides.

Sand and gravel of glacial origin are abundant in the Island Falls quadrangle. The thickest and most extensive deposits occur east of Patten near Webster and Lyman Brooks. The sand and gravel is mostly well-stratified glacial outwash. Eskers flank Lyman Brook and also the West Branch Mattawamkeag River. The eskers are extensively quarried for gravel, and at the present rate of consumption, represent ample reserves for many years. Other large eskers not currently quarried for sand and gravel occur between Crystal Lake and Crystal Brook, north of Crystal Lake along Houston Brook, along the northeast shore of Pleasant Lake, and along West Hastings Brook north of the Lane Brook tote road (International Paper Co. road). A small esker crops out east of Lane Brook
Meadows north of elevation 862 feet; it could be a convenient source of gravel for the improvement of the Lane Brook tote road.

\section{GEOPHYSICAL INVESTIGATIONS SLINGRAMI METHOD}

The slingram or "loop frame" method of electromagnetic measurement (Frischknecht, 1959) was used in the Island Falls quadrangle. Of all electromagnetic prospecting methods in current use, the slingram method and the inline moving-source dip-angle method are the most suitable for reconnaissance work. The dip-angle method requires a crew of only two men, the equipment is somewhat simpler than for the slingram method, and no connection is required between the receiver and the transmitter. However, the slingram method was chosen over the dip-angle method because it is at least as economical to use in unsurveyed areas for reconnaissance work, and for the same frequency it is better suited for defining weak conductors. In addition, the slingram method is responsive to conductors striking normal to the traverse.

A simplified sketch of the equipment used during the summer of 1961 is shown in figure 7. The coils are moved together at a fixed separation of about 100-300 feet. Of the possible coil orientations that are practical for ordinary slingram equipment, the horizontal coplanar arrangement is the most sensitive and the most commonly used.

The equipment shown in figure 7 functions as follows: The primary magnetic field from the transmitting loop induces eddy currents in conductive rocks. These eddy currents give rise to a secondary magnetic field. A voltage proportional to the vector sum of the primary and secondary fields is induced in the receiving coil. In general, at the receiving coil the secondary field is weaker and is not in phase with the primary field. The ratiometer measures the inphase and out-of-phase ratios of the receiving-coil voltage compared with a reference voltage obtained from a small coil attached to the main transmitting coil and fed to the ratiometer by a cable. In the ratiometer the RC networks develop voltages across two potentiometers which are $90^{\circ}$ out of phase with respect to each other. To make a measurement the sliders on the potentiometers are adjusted until the vector sum of the voltage between the sliders is equal in magnitude and phase to the voltage from the receiving coil; this point is indicated by a null in the tone from the headphones. Readings are taken from dials connected to the shafts of the two potentiometers. 


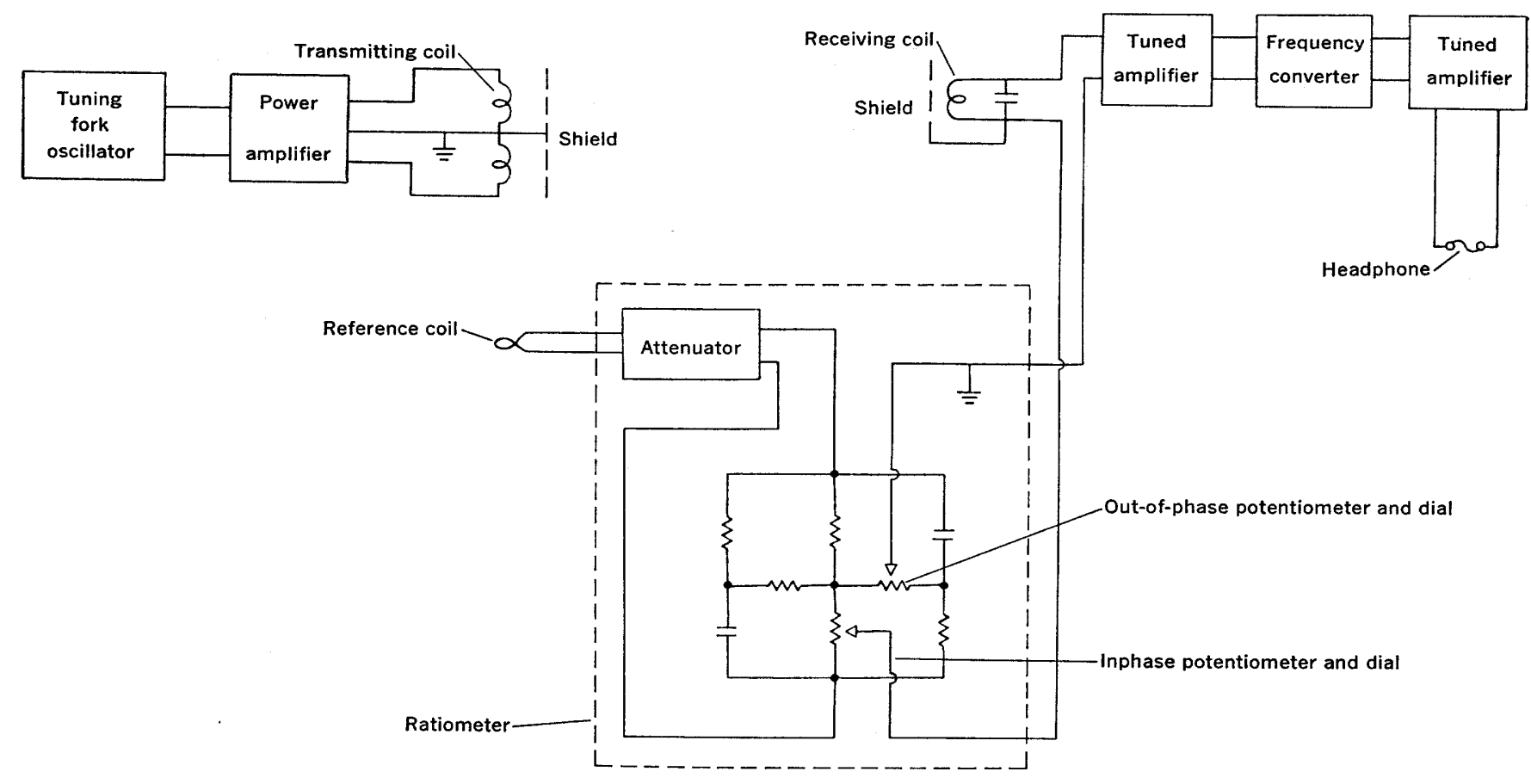

Figdre 7.-Circuit layout, slingram apparatus.

Before measurements are made, the attenuator and other zero controls (not shown in the figure) are adjusted so that the inphase and out-of-phase readings over nonconducting earth are 100 percent and 0 percent, respectively. Thus the ratio of the mutual coupling between two coils in the presence of conducting bodies to the mutual coupling between the coils in free space is measured. If the spacing of the coils is changed, or if the coil orientation is changed from coplanar to coaxial or vice versa, the attenuator must be reset, because the magnitude of the mutual coupling in free space is changed.

The magnitude of an anomaly depends upon the product of the frequency of the transmitter current, the conductivity, as well as the size, shape, and depth of burial of the conductor (Ward, 1959). For relatively small values of the product of frequency and conductivity, the out-of-phase component is larger than the inphase component, and both become larger as the frequency or conductivity, or both, increase. As the product of frequency and conductivity increases to a relatively large value, the out-of-phase component passes through a maximum and then becomes smaller, while the inphase component becomes larger, approaching an asymptotic value for very large products. A somewhat higher frequency than is usual in prospecting for ore was used in the Island Falls quadrangle in order to detect weak conductors. There are practical limits to how high a frequency should be used; in particular, thick conductive glacial drift may tend to limit penetration of high-frequency fields and may also cause local anomalies owing to variations within the glacial drift.

\section{EQUIPMENT AND FIEID TRCHNIQUES}

A ratiometer, power supply, and transmitting and receiving coils constructed by the Swedish Geological Survey, and an amplifier constructed by the U.S. Geological Survey, were used during the summer of 1959. This equipment operated at $3,600 \mathrm{cps}$ (cycles per second). For the 1960 field season new equipment intended for operation at 2,000 or 8,000 cps was constructed by the U.S. Geological Survey. Operation at 8,000 cps was not satisfactory because the self-resonant frequency of the receiving coil was only slightly greater than $8,000 \mathrm{cps}$. At $2,000 \mathrm{cps}$, the zero settings of this equipment drifted somewhat excessively, primarily because of frequency changes in the commercial LC oscillator used to drive the power amplifier. For the 1961 field season the equipment was rebuilt, and the LC oscillator was replaced by a tuning-fork oscillator, eliminating most of the drift in the zero settings. The 1961 equipment drifted slightly with changes in temperature, and small changes in zero level or "tares" sometimes occurred between traverses. The tares may have been caused by shifting of the windings within the receiving coil when the coil was jarred by rough handling. 
Under favorable conditions, the relative accuracy between adjacent stations in the out-of-phase component was about $0.5-1.0$ percent in 1959 and 1960 and about 0.25 percent in 1961 . Differences in elevation of the two coils or inexact coil spacings generally cause errors in the inphase component that are greater than the instrumental inaccuracies. Interference from 60 cps harmonics near powerlines and some telephone lines makes it impossible to obtain a sharp null, so readings taken near powerlines may be in error by several percent. Harmonic interference was almost negligible from branch lines serving only a few farms but was very pronounced from main lines.

In measurements near powerlines, secondary currents flowing in the loop formed by grounded overhead wires and the earth may cause anomalies. The REA $^{3}$ type lines are particularly effective because they carry a wire that is grounded at every guy and transformer. During traverses parallel to an REA line, such as along a road, a negative anomaly of -10 to -20 percent is observed in the out-of-phase component. The anomaly varies with distance from the line, the distance from grounding points, and other factors; therefore little reliance can be placed on measurements made less than 50-100 feet from powerlines.

For all the "regular" traverses in the Island Falls quadrangle, a standardized technique was employed using horizontal coplanar coils, a spacing of 200 feet, and a station interval of 100 feet. Experimental traverses were made using other coil spacings and orientations. In most areas underlain by conductive rocks, the glacial drift was less than 50 feet thick, so that a coil spacing of 200 feet or less gave adequate depth range even for weak conductors. To provide a satisfactory outline of the shape of an anomaly, the station interval should be no more than one half the coil spacing; thus a 100-foot spacing requires a station interval of 50 feet and is a rather slow method. A coil spacing greater than 200 feet might have been desirable for greater range in areas of thick glacial drift or to save time. However, working with long coil spacings is awkward, and in dense woods 200 feet is often the limit for voice communication between receiving and transmitting stations.

All the regular traverses were made using a frequency of either 2,000 or $3,600 \mathrm{cps}$. Two experimental traverses showed that measurement at $8,000 \mathrm{cps}$ would have been feasible in much of the quadrangle since, in most places the glacial drift is thin and has a relatively high resistivity of 500-10,000 ohm-meters as meas-

\footnotetext{
3 Rural Electrification Administration.
}

ured by L. A. Anderson of the U.S. Geological Survey. However, reliable 8,000-cps equipment was not available until 1961, too late for efficient utilization in this study.

Traverses were run mainly along roads, trails, town lines, or the edge of open fields, but where necessary, they were made along compass lines, entailing some brush cutting. Roads and trails have several disadvantages for traverses. They are usually not ideally located and do not cross the strata at a favorable angle with respect to the strike. Also, many roads and trails are so winding that the straight-line distance between coils is too short, even though the reference cable is pulled taut. Large errors in the inphase component result from traverses along winding roads, but the out-of-phase component is not seriously affected.

The measurements were made by a crew of threeone man carried the transmitting coil and transmitter, one carried the receiving coil, and the operator carried the ratiometer. The man carrying the receiving coil marked each new station with surveyor's flagging tape. Distances were chained off using marks on the reference cable.

On a good road, readings can be made at 100 -foot intervals at a rate of about $6,000-7,000$ feet per hour. In thick woods and bogs progress may be slowed to $2,000-3,000$ feet per hour. Two men can cut a suitable line through open woods at a rate of perhaps 3,000 feet per hour; in thick woods their progress is slowed to 1,500-2,000 feet per hour. About 150 man days was required to complete 105 miles of electromagnetic traverses in the summer of 1961.

\section{INTERPRETATION OF FLECTROMAGNETIC PROFILDS}

Results of electromagnetic studies, like those of many other types of geophysical investigations, are interpreted by comparison with catalogs of reference curves for different geologic situations. Because of mathematical difficulties, reference curves for electromagnetic methods are usually obtained from actual measurements over scale models rather than from calculations.

If a conductor is fairly homogeneous and has a reasonably simple shape, such parameters as thickness, depth of burial, dip, strike, and conductivity can be estimated with fair accuracy from the observed anomaly, provided suitable reference curves are available. If the conductor is a thin bed, its thickness and conductivity cannot be determined, but their product can. Most of the anomalies in the Island Falls quadrangle are complicated, and quantitative interpretation is difficult or impossible. Generally, only the position of 
the conductor or conductive belt and its total thickness or width were determined for this study. Where possible the direction of dip was predicted. The magnitudes of anomalies, which depend on both the conductivity and thickness of the conductors, were considered in correlating anomalies between traverses.

Many conductors in the Island Falls quadrangle can be approximately represented in a scale model by a single thin conductive sheet dipping almost vertically. The shapes of the anomalies over these conductors resemble the model curves (Frischknecht and Mangan, 1960) in figure 8. The conductor lies directly under the minimums and the separation between the two points at which the out-of-phase curve goes through zero (and also the two points at which the inphase curve goes through 100 percent) is approximately equal to the coil spacing. If the conductor strikes normal to the line of traverse, the separation between the subsidiary highs is only slightly greater than the coil spacing, whereas if the conductor strikes at an acute angle to the line of traverses, the distance between subsidiary highs is considerably greater than the coil spacing.

If the separation between the two 0 percent points or the two 100 percent points on the anomaly is much greater than the coil separation, the conductor has an appreciable thickness, or more than one thin conductor is present. The edges of the thick conductor or the positions of the outermost of the thin conductors are at distances approximately equal to one-half the coil spacing, measured in from the zero points. In practice the thickness of a conductor may be determined to an accuracy of about 10 percent of the coil spacing.

If the dip is not vertical, the curve is asymmetric, having one subsidiary high greater than the other. When the traverse is normal to the strike, the dip is in the direction of the greater of the two subsidiary highs. If the conductor strikes at an acute angle to the traverse, the situation is more complicated. If the inphase component is being considered, the greater of the subsidiary highs gives the direction of dip, but if the out-of-phase component is being considered the direction of dip may be toward the smaller of the two highs.

If a belt of thin conductors is traversed at an acute angle, the anomaly may be predominantly or entirely positive, or greater than 100 percent, whereas a massive conductor having the same total width as that of the belt of thin conductors and traversed at the same angle yields a negative anomaly in the center and two

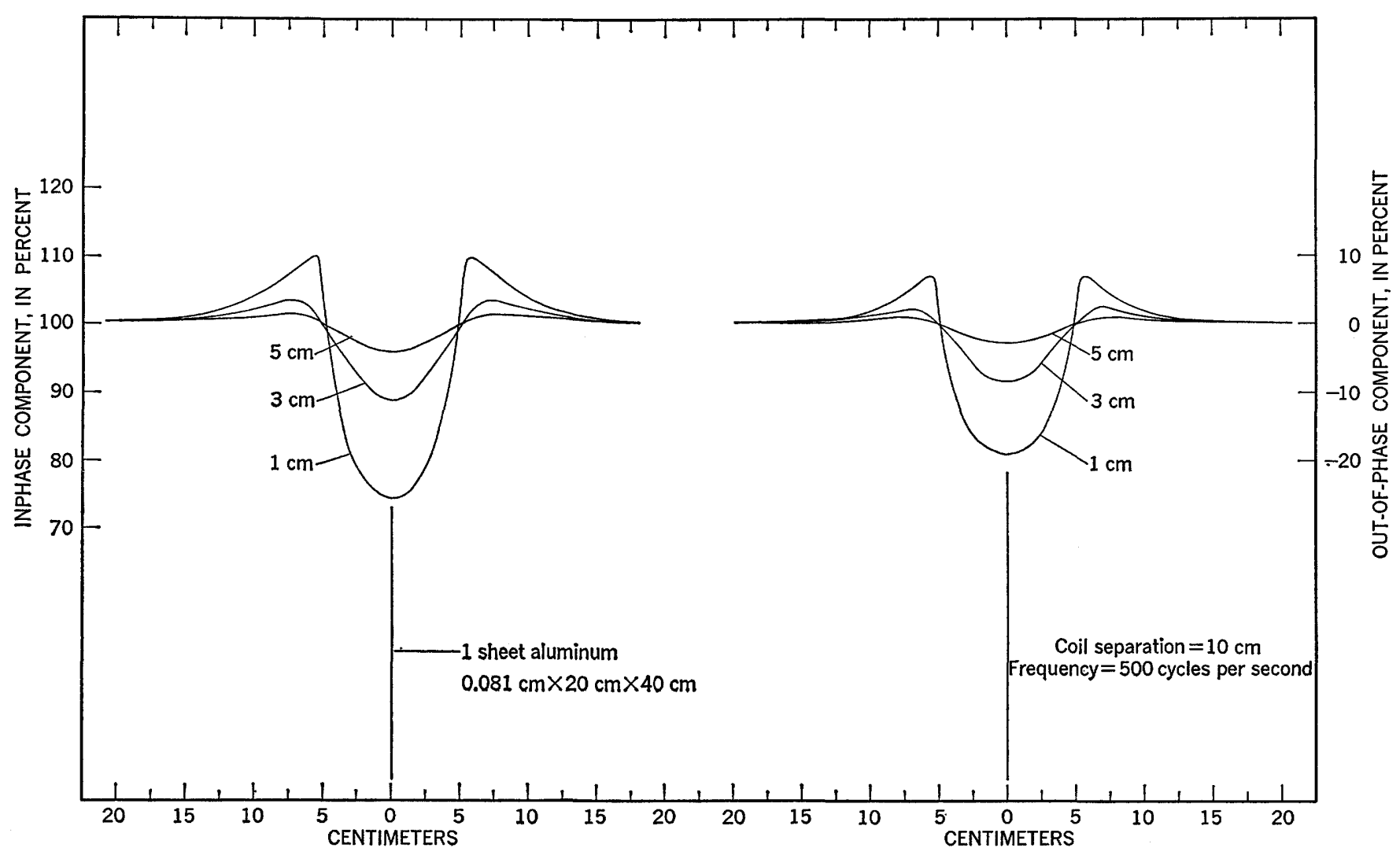

FIGURE 8.-Model curves of slingram method. 
large positive anomalies on either side. This effect is produced because the anomaly for a traverse at an acute angle to the strike over a single thin conductor may have a larger area under the positive part of the curve than under the negative part. The effects of a series of thin conductors are cumulative, so that the positive parts of the anomalies offset the negative parts. This effect has also been noted when the dip-angle method is used for traverses over schistose conductors (Swanson, 1960).

The locations of all the electromagnetic traverses were plotted on an index map (pl. 2).

The out-of-phase component for part or all of most traverses is shown. No significant anomalies occur along any traverses that were not plotted, except for T-29. In accord with common practice, anomalies are plotted so that negative anomalies appear as highs and positive anomalies as lows. No attempt was made to correct for drift or tares in the zero setting of the equipment; therefore, differences in the apparent zero level of the profiles are not significant. The profiles made at 3,600 cps are so designated; the remainder were made at $2,000 \mathrm{cps}$. Anomalous zones were correlated between traverses, and inferred conductors or conductive belts were drawn on the geologic map (pl. 1).

Because the out-of-phase component is usually larger and is not subject to errors in coil spacing, it was used almost exclusively in delineating conductive zones. In only a few circumstances does the inphase component yield better information. There is a remote possibility that some very good conductors at depth, which cause insignificant out-of-phase anomalies, were missed because care was not always taken to obtain accurate readings for the inphase component. In most areas, out-of-phase anomalies as small as $3-5$ percent were deemed significant.

The model curves for 1-cm depth (fig. 8) resemble rather closely the anomaly which occurs 3,500 feet east of the west end of T-34. Minimum values of the inphase component are 64 percent for the field anomaly (not shown) and 74.5 percent for the model anomaly; maximum values of the out-of-phase component are 25 percent for the field anomaly and 19 percent for the model anomaly. The depth of the glacial till in this area is probably less than one-tenth of the coil spacing, and the anomaly indicates that the conductive bed is dipping slightly. Both of these factors tend to increase the field anomaly over the model anomaly. The equivalent depth extent of the model is only 400 feet, but the anomalies would be little different for a sheet of infinite horizontal and depth extent. The con- ductance of the model is $2.86 \times 10^{6}$ mhos. If the proper scaling relationships are used, and the model is assumed to represent the field conductor accurately, the conductance of the field conductor is 11.75 mhos. This could correspond to a bed 5 feet thick having a resistivity of $0.130 \mathrm{ohm}$-meter or a bed 20 feet thick having a resistivity of $0.519 \mathrm{ohm}-\mathrm{meter}$. The field curves indicate that the conductor is not more than 20-30 feet thick, so the resistivity (parallel to bedding) is not more than about $0.8 \mathrm{ohm}$-meter. The ratio of the inphase to out-of-phase components for this conductor is greater than for most conductors in the Island Falls quadrangle. By comparison with other model data, the conductance of most of the conductors is estimated to be in the the range of 1-10 mhos.

\section{GRAND PITCH FORMATION}

In the Island Falls quadrangle both the Grand Pitch Formation and the Allsbury Formation bear conductive strata. In general, anomalies from the Grand Pitch are more complex than those from the Allsbury. Isolated anomalies are less common and positive anomalies are more common, even for traverses which are normal to the regional strike. The latter observation suggests that there may be considerable local folding in the black slates which does not parallel the regional strike. In detail, anomalies cannot be correlated between traverses. Although there could be lithologic reasons for it, the greater complexity of anomalies from the Grand Pitch is probably a reflection of more complex deformation.

Although individual features in the Grand Pitch Formation cannot be correlated between traverses, belts of anomalies can be traced. One major belt parallels the Silurian rocks in the northwest part of the quadrangle, another belt or series of belts occurs south of Frost and Adams Ridge, and a third belt of relatively strong conductors lies southeast of Rockabema Lake. Minor conductors occur $1 \frac{1}{2}$ miles northwest of Knowles Corner and 11/2 miles north of Pleasant Lake.

The axis of the Weeksboro-Lunksoos Lake anticline separates the belts of conductors into two groups which probably represent younger rocks on the limbs of the anticline. If so, the belt of conductive rocks southeast of Rockabema Lake is a continuation of one of the belts defined south of Frost and Adams Ridge.

North of the Lane Brook tote road, much of the entire section of the Grand Pitch contains conductive rocks; it is therefore easy to locate the contact between the Grand Pitch and other rocks by electromagnetic measurements. The same is true for the belt of Grand Pitch southeast of Rockabema Lake. 
ALISBURY FORMATION AND ROCKS AT KILGORE KNOLI

In the Allsbury Formation, three narrow prominent belts of conductors were traced for about 10 miles. Other conductors were traced for several miles. The conductivity or thickness, or both, and the number of conductors within each belt vary considerably along strike. The system of conductors is most extensive in the vicinity of the Allsbury and Clark Roads. South and west towards the Sherman and Shin Pond quadrangles, the conductors become less prominent and some pinch out. Along T-100, just south of the Island Falls boundary, all the anomalies represent isolated thin beds.

A series of closely spaced anomalies which does not carry through to adjacent traverses occurs on T-94. These anomalies may represent a repetition of the same bed; however, they are shown as isolated units, because the nature of the structure cannot be deduced. South from Myrick School, the most prominent belt of conductors in the Allsbury Formation bifurcates into belts which continue on toward the Sherman quadrangle. Other bifurcations are less pronounced.

Northeastward from the Allsbury Road, the conductors tend to converge and to weaken and pinch out. The few conductors in the area about 2 miles northwest of Batesville between Halls Corner and Mill Brook are very weak. Near Batesville several anomalies, some of them fairly large, cannot be logically connected. North of Kilgore School, the belt of conductors near the contact with the volcanic rocks of the Mount Chase area becomes much more prominent. Farther east, about 1 mile north of Batesville at Kilgore Knoll, a good conductor is present in slates and black cherts of Ordovician age. The conductor extends from immediately northwest of the intersection of Mill and Bradford Brooks almost to the West Branch Mattawamkeag River; inphase readings were as low as 33 percent (67 percent anomaly), and corresponding out-of-phase readings were 11 percent. For this ratio of the inphase to the out-of-phase component, the conductor would be classified as a good conductor in terms of measurements at $2,000 \mathrm{cps}$.

In the salient of the Allsbury Formation at Baston Brook, traverses $\mathbf{T}-20$ through $\mathbf{T}-25$ reveal the presence of large amounts of conductive strata. On T-22 and T-23 and on part of T-20, the data indicate that most of the conductors strike normal to the contact with the volcanic rocks of the Mount Chase area, thus suggesting a fault-contact. However, for a distance of about 1,700 feet along T-20, from a point 1,000 feet northwest of the intersection with $\mathrm{T}-21$, the anomaly is predominantly a positive one, indicating that in this vicinity the conductors tend to parallel the contact.
This in turn indicates that the beds locally have been folded to parallel the contact and that the salient is due in part to folding. The generally complex anomalies in the salient suggest a complicated pattern of folds.

\section{EXPERTMENTAT TRAVERSES}

Two experimental traverses were made over areas containing weak conductors, at frequencies of 2,000 and $8,000 \mathrm{cps}$, with horizontal coplanar orientation of coils. The coil stations were almost the same for both frequencies, and the coil spacings were measured with reasonable accuracy since the traverses were along straight roads.

On traverse T-59X (fig. 9) a weak conductor was mapped which intersects the traverses at about 5,200 feet east, and a zone containing three or four conductors was mapped between about 1,100 feet east and 2,000 feet east. The conductors in the latter zone intersect the traverse at a fairly sharp angle, as indicated by the relative magnitudes of the positives and negatives. On traverse T-73X (fig. 10) a minor conductor was mapped at about 4,800 feet east, and a narrow zone, probably containing two conductors, was mapped between about 700 feet east and 1,100 feet east. The anomaly at 4,800 feet east is predominantly a low, indicating that locally the conductor strikes at an acute angle to the traverse, even though, as determined by correlation with adjacent traverses, regionally the conductor is at an angle of perhaps $60^{\circ}$ with respect to the traverse. Several minor conductors, not deemed significant, occur along both traverses.

The out-of-phase curves for the two frequencies follow each other rather closely except that the anomalies at $8,000 \mathrm{cps}$ are two to four times as large as those at 2,000 cps. For the larger anomalies, the inphase curves are similar but differ considerably in detail. Perhaps some of the smaller features on the $8,000-\mathrm{cps}$ profiles, which are not shown on the geologic map, could be traced by means of closely spaced traverses. However, in this part of the quadrangle a sufficient number of conductors for mapping purposes were found with 2,000-cps measurement. In other parts of the quadrangle, where mappable units were not found with 2,000-cps measurements, useful results might have been obtained at $8,000 \mathrm{cps}$.

On T-85X (fig. 11) measurements were made at 2,000 and 8,000 cps using horizontal coplanar, vertical coaxial, and vertical coplanar coil arrangements. A faulty switch in the equipment prevented the recording of some of the readings for the 8,000-cps vertical coaxial curves. The conductive zone extends from about 350 feet east to 850 feet east. The edges of the 


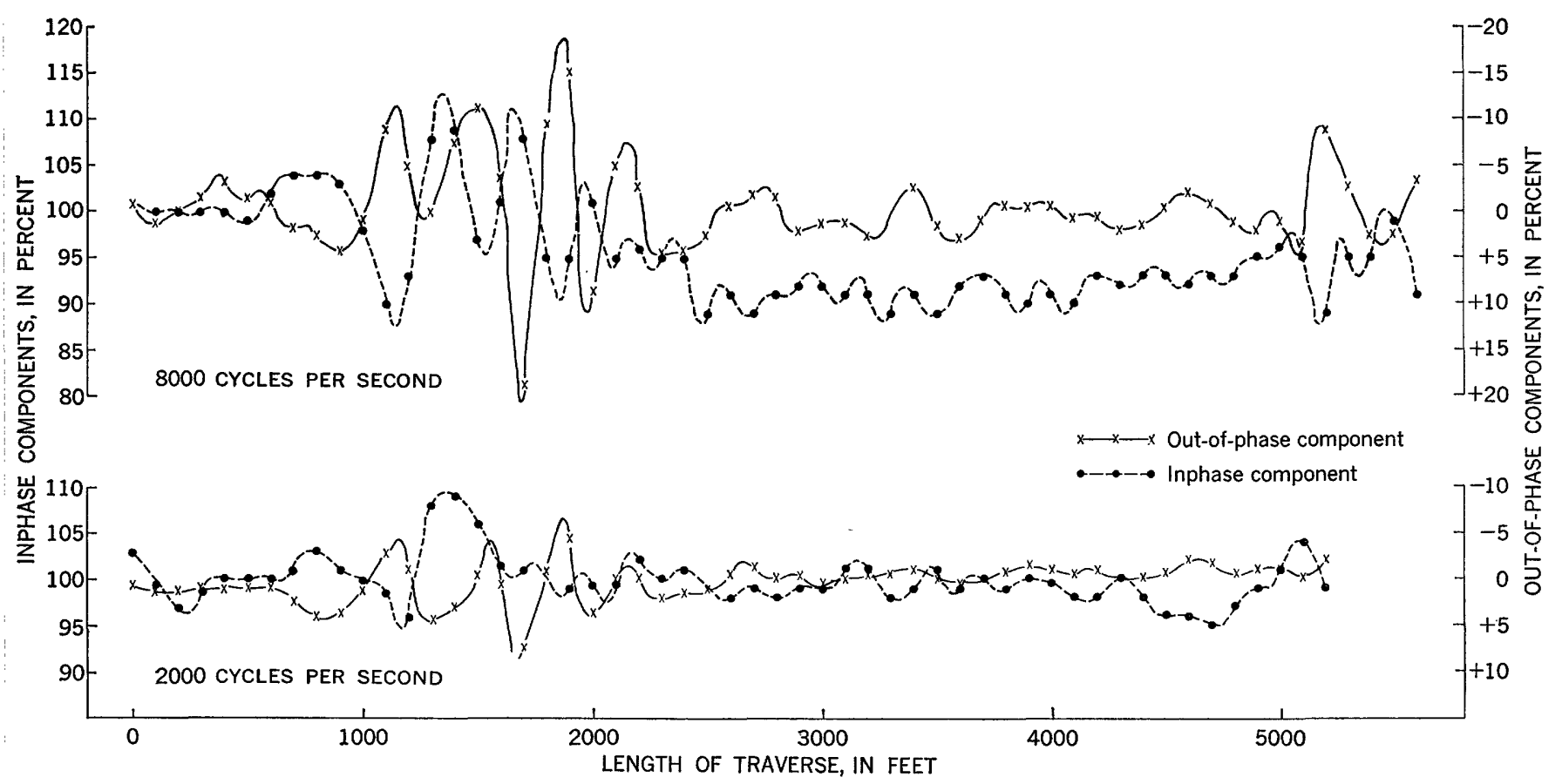

Figure 9.-Comparison of profiles at 2,000 and 8,000 cps for electromagnetic traverse T-59X.

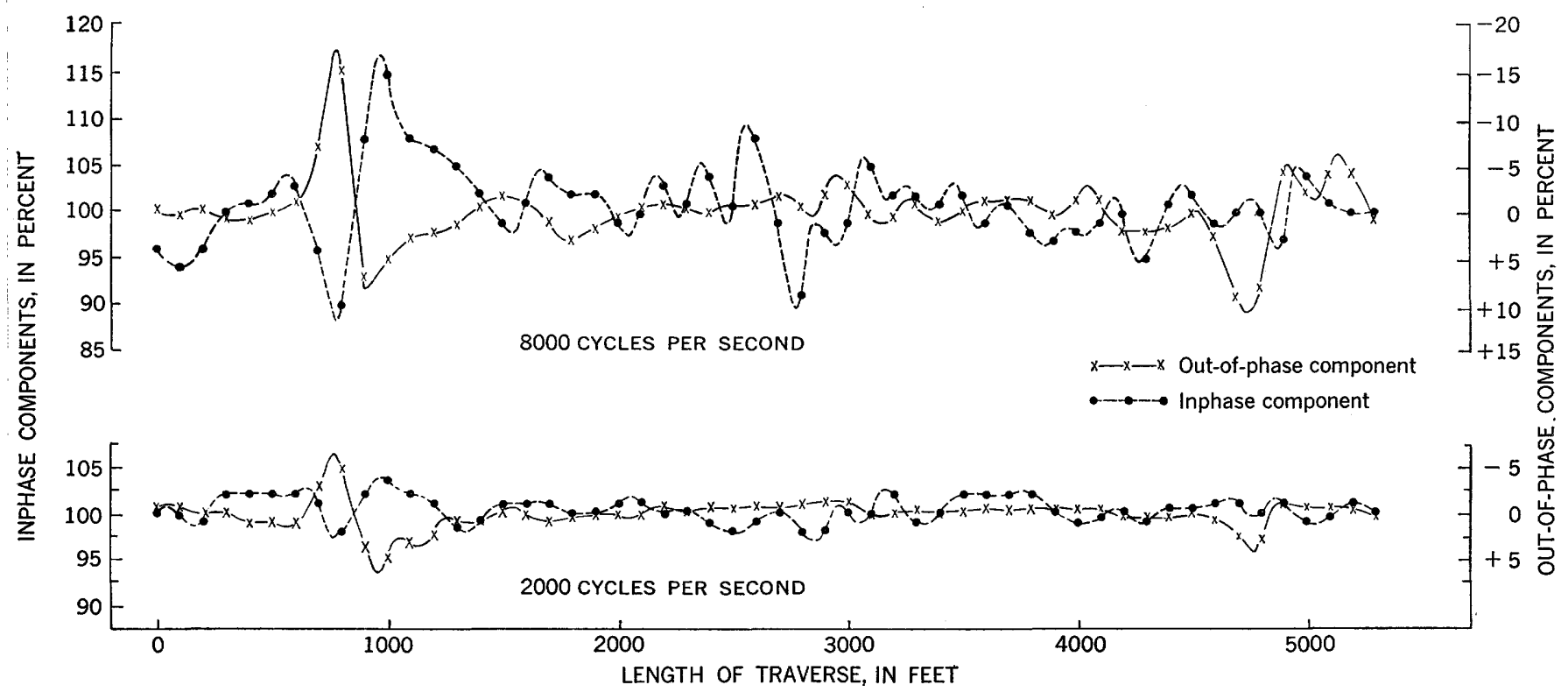

Figure 10.-Comparison of profiles at 2,000 and $8,000 \mathrm{cps}$ for electromagnetic traverse T-73X.

zone appear to have a lower conductivity than the central part. For a vertical coplanar coil arrangement, the anomaly over a thin vertical sheet striking $90^{\circ}$ is predominantly a low, and a negative for the inphase and out-of-phase components, respectively. The opposite is true for a wide massive conductor. Therefore, the conductive zone on $\mathrm{T}-85 \mathrm{X}$ must represent a series of thin conductive beds sandwiched between insulating beds, rather than one massive conductor. This interpretation is substantiated by the presence of many minor features on the curves for the other coil arrangements.

For horizontal coils, at 2,000 cps the out-of-phase curve is somewhat smoother and more suggestive of a single massive conductor than the inphase curve, whereas at $8,000 \mathrm{cps}$ the inphase curve is smoother. The 
out-of-phase curve is generally the smoothest and most nearly resembles model curves over conductors having a simple shape for relatively small values of the product
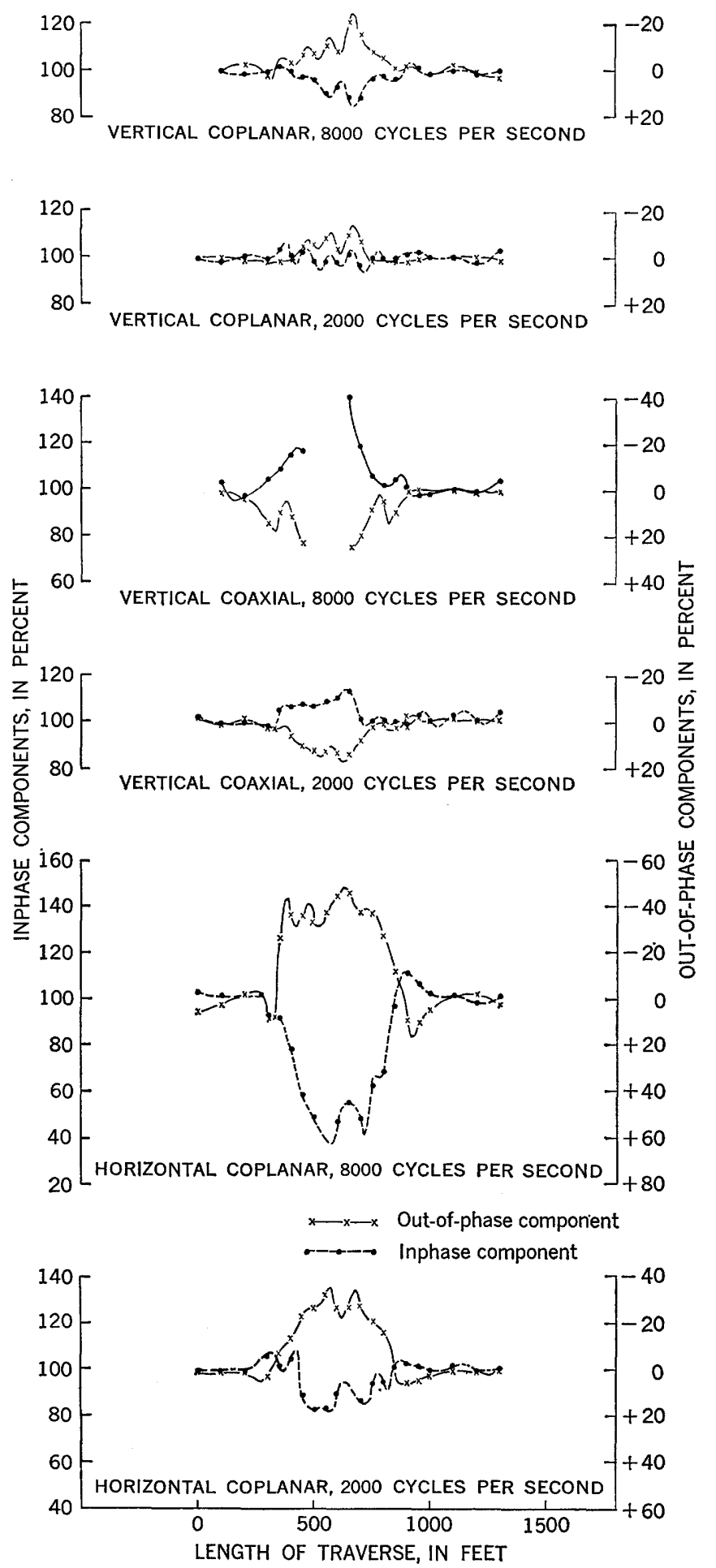

Figure 11.-Comparisons of profiles at 2,000 and 8,000 cps for horizontal coplanar, vertical coplanar, and vertical coaxial coil arrangements for electromagnetic traverse T-85X. of conductivity and frequency, whereas the inphase curve is the smoothest for relatively large values.

As usual, on T-85X the horizontal coplanar arrangement yielded the largest anomalies, and the vertical coplanar arrangement yielded the smallest.

Traverse T-94X (fig. 12) intersects three conductive zones at an angle of about $75^{\circ}$ to the strike. The westernmost zone is centered at 620 feet east on T-94X and is 50-100 feet wide. The horizontal coplanar curves indicate a westward dip of this conductor, whereas the vertical coaxial curves indicate a slight eastward dip. This discrepancy may exist because the conductor is inhomogeneous, or because the vertical coaxial curve has not been drawn properly through the measured points.

A narrow conductor, probably no wider than 20 feet, occurs at 1,820 feet east, and a weak conductor occurs at about 2,020 feet east. Although the curves for horizontal coils suggest a westward dip, the anomalies from these two conductors overlap and the dip cannot be definitely determined. At first inspection the vertical coaxial curves suggest an eastward dip, because the low on the west side of the east conductor is superimposed on the low on the east side of the west conductor. For these conductors the vertical coplanar arrangement is almost as sensitive as the vertical coaxial arrangement, and the anomalies obtained using the former arrangement are simpler.

Traverse T-95X (fig. 13) was run at an angle of about $25^{\circ}$ to the easternmost two of the conductive zones cut by $T-94 X$, to provide a comparison of results obtained at an acute angle with results obtained at a high angle.

As expected, on T-95X the anomalies for horizontal coils are predominantly highs and positives for the inphase and out-of-phase components, respectively. The axis of the minor conductor is at about 1,100 feet north and the axis of the major conductor is at about 1,520 feet north. For vertical coaxial coils the anomalies are much larger on T-95X than on T-94X, whereas for vertical coplanar coils the anomalies are smaller and are reversed in sign. Lack of comparable model data prevents a detailed interpretation of these anomalies. Comparison of the amplitudes of the anomalies obtained on T-94X and T-95X demonstrates that, in general, horizontal coils are more sensitive than vertical coils.

\section{SUMMARY OF ELECTROMAGNETIC RESULTS}

Results from the Island Falls quadrangle show that individual conducting zones or belts of conductors can be mapped continuously for many miles. Strike trends can be delineated; in addition, deductions can be made 
as to the dip of the beds and simple structures can be traced. The geologic map of the Island Falls quadrangle is much more detailed than it would have been without electromagnetic data. Also, the interpretation of some of the major features such as the northwest extension of the Weeksboro-Lunksoos Lake anticline and folding in the Baston Brook salient southeast of Mattawamkeag Hill are based on the electromagnetic and other geophysical data.

The time and cost of electromagnetic surveying are much less than for drilling or trenching to obtain comparable information. A few reconnaissance traverses suffice to locate areas containing conductors, so that an entire quadrangle need not be surveyed in detail. In the Island Falls quadrangle, considerably less time and money were spent on the electromagnetic survey than on the regular geologic mapping.

This study demonstrates that if conductive strata are present in areas extensively covered with relatively thin overburden, electromagnetic surveys can be a valuable supplement to conventional geologic mapping on a quadrangle scale. Metamorphosed rocks which are highly conductive and can be detected easily by electromagnetic measurements include black carbona-

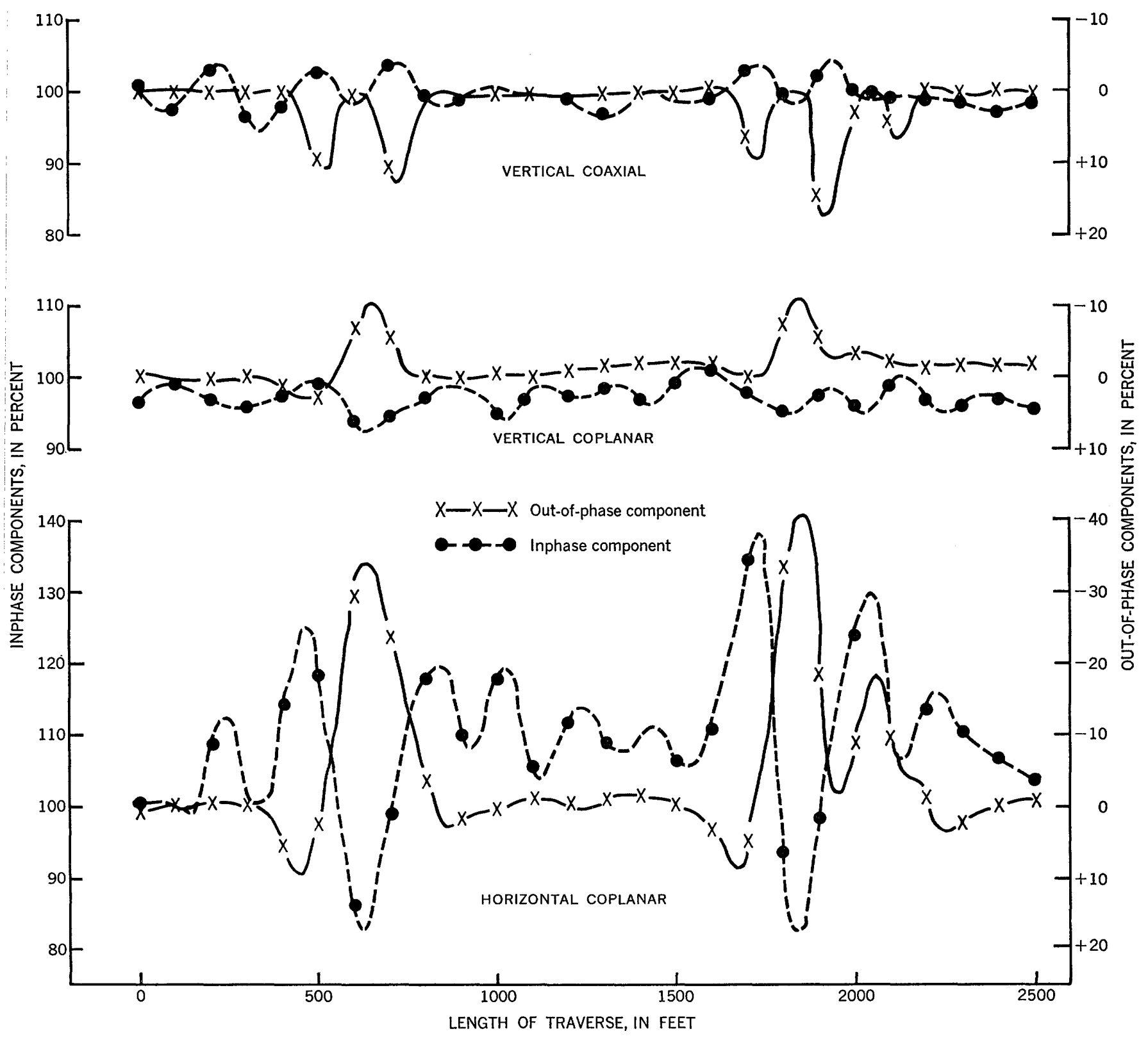

FiguRe 12.-Comparison of profiles for horizontal coplanar, vertical coplanar, and vertical coaxial coil arrangements for electromagnetic traverse $\mathrm{T}-94 \mathrm{X}$. 


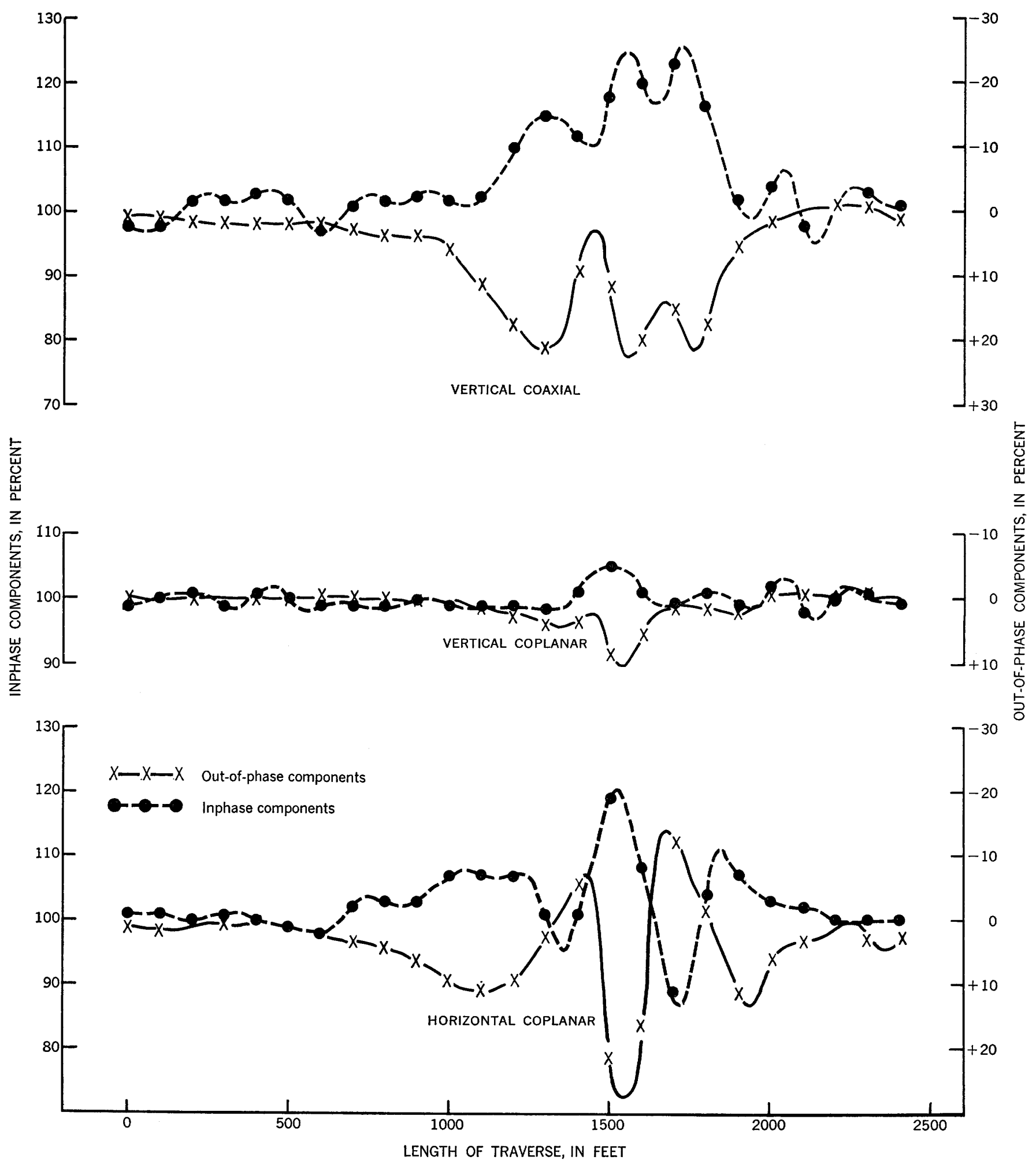

FIGURE 13.-Comparison of profiles for horizontal coplanar, vertical coplanar, and vertical coaxial coil arrangements for electromagnetic traverse $\mathrm{T}-95 \mathrm{X}$. 
ceous slate, such as is found in the Island Falls quadrangle and many other parts of northern Maine; graphitic schist; banded iron formations containing magnetite or specular hematite, such as those in the Lake Superior region; and rocks containing sulfides, such as pyrite and pyrrhotite. The grade of metamorphism and the resulting texture are as important as the percentage of conducting minerals in determining the conductivity of the rock. In the Island Falls quadrangle, chlorite-grade metamorphism was suffcient to render carbonaceous strata conductive; a much higher grade of metamorphism may be required to make rocks bearing syngenetic sulfides conductive. In order for a thin bed to be detected by 2,000-cps slingram measurements, the product of the conductivity and thickness should be about 1 mho or greater.

Improvements in electromagnetic equipment and techniques are being made, and there is increasing interest in the geology and economic resources of areas of extensive cover, which often have been ignored in the past owing to the difficulty of geologic mapping by conventional techniques. These changes should result in an increasing use of electromagnetic methods in geologic mapping.

\section{MAGNETIC SURVEYS}

An aeromagnetic map of the Island Falls quadrangle has been published without text by the U.S. Geological Survey (Dempsey, 1962).

The largest magnetic anomalies in the quadrangle occur over the mafic volcanic rocks of the Mount Chase area. Lesser anomalies are found over slate beds in the Allsbury Formation; with a few exceptions, as discussed in later pages, the other rocks exposed in the quadrangle are only slightly magnetic.

A pattern of discontinuous anomalies roughly outlines the volcanic belt along the ridges dominated by Mount Chase as far north as the West Branch Mattawamkeag River. Rocks along the southeast side of the ridge tend to be most magnetic; those on the northwest side are more silicic and less magnetic. Mapping of individual units within the volcanic rocks of the Mount Chase area is not sufficiently detailed to permit correlation of magnetic lows and highs with rock types, but in general the highs coincide with the thickest belts of spilite. Magnetic anomalies show little correlation with topographic features.

The contacts of the volcanic rocks of the Mount Chase area are not sharply defined by the aeromagnetic map; on the southeast side there are parallel anomalies in the Allsbury Formation, and on the northwest side some of the volcanic rocks are not very magnetic.
Northwest of the ridge several sharp magnetic lows occur which are probably caused by induced rather than remanent magnetization. A broad gentle low extends northwest well over the Rockabema Quartz Diorite. This low is probably due partly to very low susceptibility in the quartz diorite and partly to the lows induced by the adjacent volcanic rocks. Comparison of some individual anomalies with calculated curves indicates that the volcanic rocks in the Mount Chase ridge dip steeply to the southeast (J. W. Allingham, oral commun., 1961).

Northeast of the West Branch Mattawamkeag River, the anomalies over the volcanic rocks of the Mount Chase area are relatively small. They serve to distinguish volcanic rocks from the quartz diorite on the north, but not from the Allsbury Formation on the south.

At Green Mountain and the Lane Brook Hills, the volcanic rocks are outlined by a magnetic trend which is more pronounced farther west in the Shin Pond quadrangle. Small anomalies indicate that a unit of these volcanic rocks strikes northeast through Lane Brook Pond.

Moderately large magnetic anomalies, particularly near the ridge extending from Mount Chase to Shoaler Mountain, distinguish the Allsbury Formation from other sedimentary units in the quadrangle. Individual magnetic units within the Allsbury Formation are not well defined by the aeromagnetic map. For the present study, therefore, a few ground magnetic traverses across the Allsbury Formation were run to aid in the interpretation of the aeromagnetic data. A Schmidttype vertical balance was used. No corrections were made for diurnal variations, which appeared to be small relative to the magnitude of the anomalies; the same arbitrary datum was selected for all traverses.

The ground magnetic results correlated in part with electromagnetic results, so the two sets of data are plotted together on coincident profiles (fig. 14). The sharpness of the magnetic anomalies indicates that the magnetic rocks are near the surface.

Traverses T-29M and T-30M (fig. 14) show that the conductive black slate and chert at Kilgore Knoll are responsible for an 800-gamma anomaly. These rocks are much more magnetic than the adjacent volcanic rocks. In the middle of $\mathrm{T}-29$ and $\mathrm{T}-29 \mathrm{M}$ there is good correlation between an electromagnetic low, caused by a conductive zone striking at an acute angle to the traverse, and a broad magnetic high. Also, on $\mathrm{T}-43 \mathrm{M}$ and $\mathrm{T}-29 \mathrm{M}$ magnetic anomalies correlate in part with very weak electromagnetic anomalies.

Traverse $T-41 \mathrm{M}$ and the corresponding part of $\mathrm{T}-41$ are both flat. 


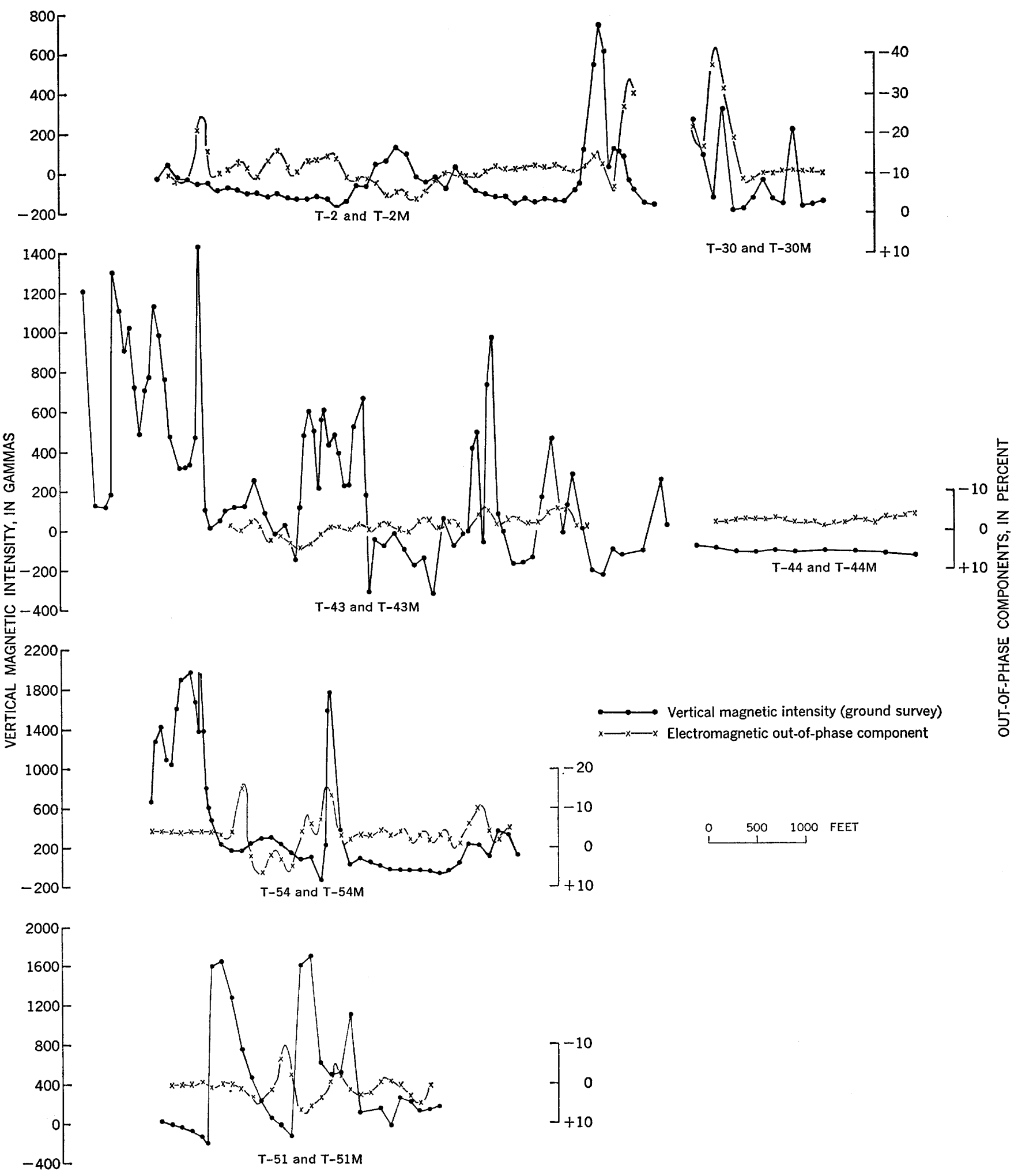

FIgURe 14.-Comparison of ground magnetic and electromagnetic profiles for selected traverses. 
On T-54 and T-54M there is good correspondence between two electromagnetic and two magnetic anomalies. On this traverse the edge of the conductive zone either coincides with the contact between the volcanic rocks and sedimentary rocks or is very close to it.

The only ground magnetic anomaly that is sufficiently smooth to permit quantitative interpretation is at the west end of T-51M. Outcrops of volcanic rocks striking northeast were observed near the peak. The anomaly must be caused by a sill or other distinct unit dipping to the southwest. Such a dip is indicated also by the fact that the edge of the conductive zone overlaps the beginning of the magnetic anomaly; conductive rocks must therefore overlie the downdip part of the magnetic unit. Magnetic anomalies occur in the conductive belt, although individual peaks do not coincide with electromagnetic peaks.

As far as is known, most of the magnetic beds in the Allsbury Formation are dark slates containing magnetite as the primary magnetic constituent. The linear nature of the aeromagnetic anomalies and their coincidence with conductive zones indicate that the magnetic beds are probably continuous. It is very likely, that detailed ground magnetic surveys would have been a valuable supplement to the electromagnetic method, particularly in areas such as the vicinity of $\mathrm{T}-43$, where the electromagnetic anomalies are very weak.

The elongated aeromagnetic anomalies which occur 2-4 miles south of Knowles Corner and immediately northeast of Baston Brook tend to confirm the presence of black slates as deduced from the electromagnetic results. All of the magnetic trends in the Allsbury Formation are interrupted by a low that follows the West Branch Mattawamkeag River. A small anomaly at De Lette Ridge is probably related to the presence of hornfels around the intrusive mass of granite, and the small, sharp anomalies east and northeast of the town of Island Falls may be caused by disseminated pyrrhotite in the contact-metamorphic zone surrounding the Pleasant Lake pluton.

The contours swinging in a gentle arc about Belvedere School at the south border of the quadrangle suggest a large magnetic body at depth in the Sherman quadrangle.

Small aeromagnetic anomalies of unknown origin occur over the Grand Pitch Formation northeast of Frost and Adams Ridge, southwest of Knowles Corner, and southwest of Green Mountain Pond. The anomaly southwest of Knowles Corner is near the contact of the Grand Pitch Formation with the Rockabema Quartz Diorite, and may be caused by magnetite asso- ciated with the intrusion. A small magnetic trend in the northwest corner of the quadrangle probably coincides with an outcrop of quartz porphyry in the belt of undifferentiated Silurian rocks near Lane Brook. The magnetic gradient in the extreme northwest corner of the quadrangle is related to a large volcanic mass that crops out to the west in the Shin Pond quadrangle; the gradient is probably also related to unknown magnetic bodies immediately north of the quadrangle boundary as inferred from the aeromagnetic map of the adjoining Oxbow quadrangle. Volcanic rocks may underlie the northwest limb of the Wadeligh Bog syncline at shallow depth.

The aeromagnetic map provided a valuable framework for the geologic studies of the quadrangle by outlining areas containing magnetic rocks at or near the surface. In a few localities, geologic contacts are inferred from the aeromagnetic map, although, in general, the resolution of the aeromagnetic data is not adequate for locating contacts. The ground magnetic traverses pinpointed the sources of the magnetic anomalies in the Allsbury Formation, and detailed ground magnetic surveys might have been a valuable supplement to the electromagnetic surveys in tracing marker beds within the Allsbury. Subunits could probably be delineated in the volcanic rocks of the Mount Chase area by ground magnetic surveys. Additional magnetic surveys would not have been helpful in mapping units within the Grand Pitch Formation. There are several very small anomalies in the Mattawamkeag Formation, and a few beds within this formation might have been traced by ground magnetic surveys.

\section{REFERENCES CITED}

Boucot, A. J., 1961, Stratigraphy of the Moose River synclinorium, Maine: U.S. Geol. Survey Bull. 1111-E, p. 153-188.

Daly, R. A., 1914, Igneous rocks and their origin: New York, McGraw-Hill Book Co., 563 p.

Dempsey, W. J., 1962, Aeromagnetic map of the Island Falls quadrangle, Aroostook and Penobscot Counties, Maine: U.S. Geol. Survey Geophys. Inv. Map GP-293.

Dickinson, W. R., 1962, Metasomatic quartz keratophyre in central Oregon: Am. Jour. Sci., v. 260, p. 249-266.

Ekren, E. B., 1961, Volcanic rocks of Ordovician age in the Mount Chase ridge, Island Falls quadrangle, Maine, in Short papers in the geologic and hydrologic sciences: U.S. Geol. Survey Prof. Paper 424-D, p. D43-D46.

Faul, Henry, Stern, T. W., Thomas, H. H., and Elmore, P. L. D., 1963, Ages of intrusion and metamorphism in the northern Appalachians: Am. Jour. Sci., v. 261, p. 1-19.

Frischknecht, F. C., 1959, Scandinavian electromagnetic prospecting: Am. Inst. Mining Metall. Engineers Trans., v. 214, p. 932-937.

Frischknecht, F. C., and Ekren, E. B., 1960, Mapping conductive strata by electromagnetic methods, in Short papers in the geological sciences: U.S. Geol. Survey Prof. Paper 400-B, p. B121-B125. 
Frischknecht, F. C., and Mangan, G. B., 1960, Preliminary report on electromagnetic model studies: U.S. Geol. Survey open-file report, $12 \mathrm{p}$.

Gilluly, James, 1935, Keratophyres of eastern Oregon and the spilite problem: Am. Jour. Sci., ser. 5, v. 29, p. 225-252, 336-352.

Harker, Alfred, 1956, Metamorphism: 3d ed. New York, E. P. Dutton \& Co., 362 p.

Neuerburg, G. J., 1961, A method of mineral separation using hydrofluoric acid: Am. Mineralogist, v. 46, p. 1498-1501.

Neuman, R. B., 1960, Pre-Silurian stratigraphy in the Shin Pond and Stacyville quadrangles, Maine, in Short papers in the geological sciences: U.S. Geol. Survey Prof. Paper 400-B, p. B166-B168.

1962, The Grand Pitch Formation-new name for the Grand Falls Formation (Cambrian?) in northeastern Maine: Am. Jour. Sci., v. 260, p. 794-797.

-1964, Fossils in Ordovician tuff, northeastern Maine: U.S. Geol. Survey Bull. 1181-E, 38 p.

1967, Bedrock geology of the Shin Pond and Stacyville quadrangles, Maine: U.S. Geol. Survey Prof. Paper 524-I (in press).

Orville, P. M., 1963, Alkali ion exchange between vapor feldspar phases: Am. Jour. Sci., v. 261, p. 201-237.

Pavlides, Louis, 1962, Geology and manganese deposits of the Maple and Hovey Mountains area, Aroostook County, Maine: U.S. Geol. Survey Prof. Paper 362, 116 p. [1963].

Pavlides, Louis, and Berry, W. B. N., 1966, Graptolite-bearing
Silurian rocks of the Houlton-Smyrna Mills area, Aroostook County, Maine, in Geological Survey research 1966: U.S. Geol. Survey Prof. Paper 550-B, p. B51-B61.

Pavlides, Louis, and Canney, F. C., 1964, Geological and geochemical reconnaissance, southern part of the Smyrna Mills quadrangle, Aroostook County, Maine, in Short papers in geology and hydrology: U.S. Geol. Survey Prof. Paper 475-D, p. D96-D99.

Pavlides, Louis, Mencher, Ely, Naylor, R. S., and Boucot, A. J., 1964, Outline of the stratigraphic and tectonic features of northeastern Maine, in Short papers in the geological sciences: U.S. Geol. Survey Prof. Paper 501-C, p. C28-C38.

Pavlides, Louis, Neuman, R. B., and Berry, W. B. N., 1961, Age of the "ribbon rock" of Aroostook County, Maine, in Short papers in the geologic and hydrologic sciences: U.S. Geol. Survey Prof. Paper 424-B, p. B65-B67.

Ruedemann, Rudolf, 1942, Oldhamia and the Rensselaer grit problem: New York State Mus. Bull. 327, p. 5-18.

Ruedemann, Rudolf, and Smith, E. S. C., 1935, The Ordovician in Maine: Am. Jour. Sci., ser. 5, v. 30, p. 353-355.

Smith, E. S. C., 1928, The Cambrian in northern Maine: Am. Jour. Sci., ser. 5, v. 15, p. 484-486.

Swanson, H. E., 1960, Model studies of an apparatus for electromagnetic prospecting: Am. Inst. Mining Metall. Engineers preprint $60 \mathrm{~L} 83$.

Ward, S. H., 1959, Unique determination of conductivity, susceptibility, size and depth in multifrequency electromagnetic exploration: Geophysics, v. 24, p. 531-546. 